\title{
The role of micro-RNAs in the female reproductive tract
}

\author{
Warren B Nothnick \\ Departments of Obstetrics and Gynecology and Molecular and Integrative Physiology, University of Kansas Medical \\ Center, Kansas City, Kansas 66160, USA
}

Correspondence should be addressed to W B Nothnick; Email: wnothnic@kumc.edu

\begin{abstract}
Proper development and function of the female reproductive tract are essential for successful reproduction. Regulation of the differentiated functions of the organs that make up the female reproductive tract is well established to occur at multiple levels including transcription, translation, and posttranslational modifications. Micro-RNA (miRNA)-mediated posttranscriptional gene regulation has emerged as a fundamental mechanism controlling normal tissue development and function. Emerging evidence indicates that miRNAs are expressed within the organs of the female reproductive tract where they function to regulate cellular pathways necessary for proper function of these organs. In this review, the functional significance of miRNAs in the development and function of the organs of the female reproductive tract is discussed. Initial discussion focuses on the role of miRNAs in the development of the organs of the female reproductive tract highlighting recent studies that clearly demonstrate that mice with disrupted Dicer1 expression are sterile, fail to develop uterine glands, and have muted estrogen responsiveness. Next, emphasis moves to discussion on our current knowledge on the characterization of miRNA expression in each of the organs of the female reproductive tract. When possible, information is presented and discussed with respect to regulation, function, and/or functional targets of these miRNA within each specific organ of the female reproductive tract.

Reproduction (2012) 143 559-576
\end{abstract}

\section{Introduction}

The female reproductive tract is composed of the ovary, oviduct/fallopian tube, cervix, and uterus. For sustained and successful reproduction, proper development and function of each component is imperative. For normal development and function, a myriad of gene transcription, translation, and posttranslational regulatory mechanisms must be invoked. Unfortunately, our understanding of organogenesis and the molecular mechanisms that regulate the development and differentiation of these tissues lags behind other organ systems. Moreover, recent observations suggest that in addition to transcription, translation, and posttranslational modifications, posttranscriptional gene regulation may play a more pronounced role in cell, tissue, and organ function. In the past several years, micro-RNAs (miRNAs) have been demonstrated to play a novel, yet not thoroughly defined, role in posttranscriptional regulation of gene expression and organ development. The objective of the current review is to summarize our current understanding of those miRNAs that are expressed within the ovary, oviduct, uterus, and cervix. Emphasis is placed upon expression, regulation, and function (where possible) during the course of the menstrual/ reproductive cycle.

\section{miRNAs as posttranscriptional regulators}

miRNAs are a class of small noncoding regulatory RNAs (18-25 nucleotides) that regulate gene expression posttranscriptionally (Bartel 2004, Vasudevan et al. 2007) and are postulated to play a role in normal biological processes while their misexpression has been associated with numerous diseases. miRNA genes primarily reside between genes (intergenic) or within introns (intronic) of genes. Although less common, miRNAs have also been discovered to makeup entire introns as well as reside with exons (Berezikov et al. 2007, Saini et al. 2007). miRNA transcription is most likely mediated by polymerase II or III as the initial long primary RNA transcript (pri-miRNA) is capped (MGpppG) and polyadenylated (Cai et al. 2004). miRNA transcription begins with the nucleus where the pri-miRNA transcript binds with the RNA-binding protein DGCR8 (DiGeorge syndrome critical region 8). The pri-miRNA-DCGR8 complex is then cleaved by Drosha (an RNAse III enzyme) yielding an $\sim 70$ nucleotide stem-loop precursor miRNA (pre-miRNA). The pre-miRNA is then exported from the nucleus via exportin 5 and RAN-GTP into the cytoplasm. Once in the cytoplasm, a second RNAse III enzyme, DICER, cleaves the pre-miRNA into a transient RNA duplex of 18-25 nucleotides. Cleavage of the duplex results in 
the generation of two strands with one strand being degraded. The remaining strand is preferentially loaded onto the RNA-induced silencing complex (RISC). The RISC is composed of DICER, a TAR RNA-binding protein (referred to as TRBP) and one of the four different Argonaute (Argo) proteins (Hutvagner \& Simard 2008). Once within the RISC, miRNAs bind to the $3^{\prime}$-UTR (or UTR) of the target mRNA transcript. If the binding of the miRNA to the 3'-UTR 'seed sequence' exhibits perfect base-pairing, the mRNA transcript is degraded and mRNA translation does not occur (Jackson \& Standart 2007). If bp binding homology between miRNA and 3'UTR of the mRNA is imperfect, mRNA translation is inhibited. This most likely occurs via an inhibition of translation after initiation (Jackson \& Standart 2007) or through an RISC interaction with eukaryotic translation initiation factor 6 (EIF6) preventing assembly of $80 \mathrm{~S}$ ribosomes (Chendrimada et al. 2007). While the majority of the literature supports the notion that miRNAs inhibit translation, there is some evidence that miRNAs can actually enhance translation through alterations in the Argo component of the RISC (Vasudevan et al. 2007). Thus, while miRNAs appear to primarily regulate translation in an inhibitory manner, they may also enhance translation in certain biological scenarios.

\section{Functional role of miRNAs during the development of the female reproductive tract}

Much like other organ systems (Harfe et al. 2005, Harris et al. 2006, O'Rourke et al. 2007), miRNAs/small RNAs have been shown to be essential for proper development and function of the female reproductive tract. Using a mouse mutant with a hypomorphic Dicer1 allele, Otsuka et al. (2008) were the first to demonstrate that Dicer1 deficiency resulted in female infertility. In this study, loss of Dicer1 expression using gene-trap technology resulted in luteal insufficiency and inability to support pregnancy. Associated with these deficiencies was a lack of miR-17-5p and let $7 b$, which are putative regulators of the antiangiogenic factor TIMP1.

Subsequent studies have also demonstrated reproductive tract abnormalities (such as oviductal cysts, shortened uterine horns and altered oocyte/embryo development) and infertility in female mice in which Dicer1 was inactivated in Müllerian duct mesenchymederived tissues of the reproductive tract using an Amhr2Cre allele (Nagaraja et al. 2008). Similarly, Hong et al. (2008) observed similar oviduct and uterine defects but no significant impact of Dicer1 deletion on ovulation rates or embryo development in vitro. However, embryos collected from day 3 of pregnancy in vivo were developmentally delayed in Dicer1-deficient mice compared with wild-type counterparts. Gonzalez \& Behringer (2009) also observed similar defects within the oviduct, degenerated/unfertilized oocytes within the oviductal cysts and an inability to establish pregnancy. Further, histological analysis demonstrated that Dicer1deficient uteri contained less glandular tissue and exhibited what appeared to be early stage adenomyosis. Most recently, Lei et al. (2010) explored the role of miRNAs in mouse ovarian development using mice in which Dicer1 was deleted specifically in follicular granulosa cells. Conditional inactivation of Dicer1 in the follicular granulosa cells led to an increased endowment of the primordial follicle pool, accelerated early follicle recruitment, and exhibited more degenerate follicles. Taken together, the infertility and reproductive tract abnormalities characteristic of Dicer1-deficient female mice strongly suggest that Dicer1 function and miRNA-mediated posttranscriptional gene regulation are essential for normal female reproductive tract development and function. In the following paragraphs, a presentation of our current knowledge on miRNA expression in each component of the female reproductive tract is presented. When possible, the biological function(s) regulated by these miRNAs and their posttranscriptional target(s) that impact these processes are discussed.

\section{miRNA profiles, regulation, and function in the female reproductive tract}

Our understanding of the expression, regulation, and function of specific miRNAs in the organs of the female reproductive tract is just beginning to emerge. The first report, by Liang et al. (2007), examined global profiles of distribution and expression of 345 unique miRNAs in 40 normal human tissues obtained from commercial sources. Table 1 displays the most abundant miRNAs $\left(C_{\mathrm{t}}\right.$ value of 23 or less) detected in the ovary, fallopian tube, uterus, and cervix detected in their study. Notably, all organs expressed abundant levels of miR-26a, which has been shown to suppress cell proliferation and tumor growth (Lu et al. 2011). miR-26b is also expressed in high levels in fallopian tube, uterus, and cervix but not in the ovary and is proposed to regulate apoptosis (Liu et al. 2011). miR-26a expression was also noted to be abundant in bovine thymus, lymph nodes,

Table 1 Most abundant micro-RNAs (miRNAs) in organs of the human female reproductive tract.

\begin{tabular}{llll}
\hline \multicolumn{3}{c}{ Organ } & \\
\hline Ovary & Fallopian tube & Uterus & Cervix \\
\hline miR-26a & miR-26a & miR-26a & miR-26a \\
miR-125b & miR-26b & miR-26b & miR-26b \\
let7c & miR-21 & miR-125b & miR-29a \\
& & miR-16 & miR-21 \\
& & let7c & miR-23b \\
& & $m i R-24$ \\
& & miR-99a
\end{tabular}


small intestines, and embryo (Coutinho et al. 2007). From a functional standpoint, miR-26a over-expression is associated with myogenesis, and this is postulated to occur via posttranscriptional repression of Enhancer of Zeste homolog 2 (EZH2; Wong \& Tellam 2008). Subsequent studies have revealed that miR-26a suppresses tumor proliferation by targeting PTEN (Huse et al. 2009) and itself is repressed by MYC (Sander et al. 2008). Along these lines, Zhang et al. (2011) recently demonstrated that downregulation of miR-26a antagonizes apoptosis and facilitates carcinogenesis via the regulation of $\mathrm{EZH} 2$ and $\mathrm{MTDH}$. Whether miR-26a plays a similar role in the tissue/cells of the female reproductive tract yet remains to be determined.

Since the initial reports that characterized the expression of miRNAs in the reproductive organs of the female tract, numerous studies have been conducted to further define the miRNA profiles as well as their regulation and/or function. In the following, miRNA expression, regulation, function, and identified targets of these miRNAs, whereby these cellular processes are mediated, are discussed.

\section{Ovary}

The ovary is essential not only for the production of steroid hormones that prepare the uterus for pregnancy and support pregnancy but also to provide the female gamete that, when fertilized, will develop into a newborn. Within the context of ovarian biology, expression of ovarian miRNAs has been assessed in humans as well as rodents with primary emphasis on the period of follicle growth and ovulation. Choi et al. (2007) profiled miRNA expression in the ovaries of newborn mice and found miR-26a and let7c (both of which were identified in human ovarian tissue (Liang et al. 2007) to be among the most abundant miRNAs in this tissue. Further, miR-709, which has been identified as a novel murine miRNA for which there is no human homolog, was the most abundant of all miRNAs detected in this study. In a subsequent study, Ro et al. (2007) cloned 122 miRNAs from the ovaries of 2-week-old and adult mice and further identified 15 novel miRNAs not reported by Choi et al. (2007). Most recently, Ahn et al. (2010) performed massive parallel sequencing and identified four novel miRNAs in addition to demonstrating that the let7 family members and miR-26a (miR-26a-1) were among the most abundant miRNAs expressed in newborn mouse ovarian tissue.

Functional roles for specific miRNAs within the development of the ovary are just beginning to emerge. miR-503, which is highly abundant in mouse ovary, was shown to be markedly downregulated in the ovaries of Dicer1 null mice (Lei et al. 2010). Using a gonadotropininduced follicular development regime, they noticed in wild-type mice that miR-503 was downregulated during early follicular development but increased during later stages, just before ovulation. However, these levels were only about one-half of those in unstimulated mouse ovaries. During luteinization and development of the corpus luteum, miR-503 levels further decline (about $1 / 10$ of unstimulated ovary levels) to nondetectable levels in mature corpus lutea. Upregulation of miR-503 in granulosa cells demonstrated that this miRNA downregulated the expression of many target (Acvr2a (ActRIla), Acvr2b (ActRIIb), Fshr, Bcl2, and Ccnd2) and nontarget (Inha, Inhba, Inhbb, Cyp19a1 (Cyp19a), Lhcgr, Esr2, Ar, Cdkn1b, and Casp3) genes associated with granulosa cell proliferation and luteinization.

In the mouse, miRNA-mediated posttranscriptional regulation is required for embryonic germ cell development (Hayashi et al. 2008), but the role of individual miRNAs in their development remains unclear. miRNAs from the miR-290 cluster and the miR-290-295 clusters are the most abundant miRNAs in mouse embryonic stem cells (Calabrese et al. 2007), and they are the first embryonic miRNAs upregulated in the zygote (Tang et al. 2007). As this information implies that the miR290-295 clusters may be vital to early development of mouse, Medeiros et al. (2011) generated miR-290-295 mutant mice by targeted disruption in embryonic stem cells. While disruption of miR-290-295 resulted in partial penetrant lethality of mutant embryos, it was also demonstrated that surviving mutant embryos produced female offspring that were infertile, while males showed no such defects. Further analysis revealed that the female infertility was due to premature ovarian failure. Thus, it appears that the miR-290-295 clusters are essential for proper ovary and follicle development.

miRNA expression profiling of mouse embryonic gonads (Takada et al. 2009) identified miRNAs that were expressed in a sex-dependent manner identifying miR-29b as female-enriched miRNA. Within the ovaries, miR-29b increased from embryonic days 13.5-17.5 and was localized to primordial germ cells. Using luciferase reporter assays, Takada et al. (2009) also demonstrated that miR-29b targets the DNA methylation enzymes, DNMT3A and DNMT3B. These data may suggest that miR-29 represses expression of these enzymes allowing in female germ cells to allow escape from male-type methylation of the genome and allow proper development of the ovaries.

While the majority of these studies have focused on mouse ovary, Mishima et al. (2008) assessed miRNA expression in adult ovarian tissue and identified159 miRNA genes with miR-125b being one of the most abundant miRNAs expressed. To this point, miR-26a appears to be one of the most abundantly expressed miRNAs in both human and newborn mouse ovaries. However, to date, the localization, regulation, and function of this miRNA in ovarian function remain unknown.

More recently, Childs et al. (2012) examined the impact of $L E T 7$ family members on ovary development 
in the humans. The RNA binding protein, LIN28a (LIN28) is known to target the LET7 family of miRNAs and its expression decreases at the time during which sex determination occurs and immediately before entry into meiosis (West et al. 2009) in the female. The LIN28a targets pri-LET7a/f/d and pri-LET7g miRNAs decreased between 8- to 11-week gestational age (wga) and 14-16 wga, mirroring the changes in LIN28a expression during the process of germ cell differentiation. Thus, it appears that the $L E T 7$ family of miRNAs may be important in the developing ovary.

In addition to focusing on whole ovarian tissue expression profiles, research has also focused more on miRNA expression and function within specific ovarian cell types that play a role in ovarian function (Tables 2 and 3). One of the first reports using mouse mural granulosa cells (Fiedler et al. 2008) revealed that in vivo 196 and 206 detectable miRNA transcripts were present at 0 and $4 \mathrm{~h}$, respectively, following in vivo human chorionic gonadotropin (hCG) administration. Further analysis revealed that hCG significantly increased the expression of 13 miRNAs ( 4 vs 0 h). Of these, $m i R-132$ and miR-212 as well as $m i R-21$ were the most significantly upregulated. Further studies using isolated granulosa cell culture experiments verified this pattern of expression for $m i R-132$ and $m i R-212$. To determine whether either of these miRNAs impact granulosa estrogen and/or progesterone production, miR-132 and miR-212 expression was knocked down using LNA molecules. Knockdown of miR-132 and miR-212 alone or in combination had no effect on granulosa steroid production.

A subsequent study by this same group (Carletti et al. 2010) demonstrated that $m i R-21$ plays an antiapoptotic role in ovarian granulosa cells. Knockdown of $m i R-21$ in granulosa cells in vitro as well as in vivo knockdown of whole ovarian miR-21 expression resulted in increased apoptosis. Further, the in vivo knockdown of $m i R-21$ was associated with a reduced ovulation rate. Although $m i R-21$ was proposed to mediate granulosa cell/ovarian tissue apoptosis, the authors could not demonstrate an alteration in the levels of protein expression of the miR-21 apoptosis-regulating targets programmed cell death, PTEN, tropomyosin-1, and sprouty homolog 2, suggesting that $m i R-21$ regulation of apoptosis within the ovary may occur via yet unidentified miR-21 targets.

miRNAs that control ovarian cell apoptosis and proliferation have also been examined in humans (Sirotkin et al. 2010). Ovarian granulosa cells were transfected with different constructs encoding premiRNAs, and proliferation and apoptosis were assessed by immunohistochemical localization of PCNA and BAX respectively. Eleven miRNAs stimulated while 53 inhibited expression of PCNA (Table 2). Further, 11 miRNAs stimulated and 46 reduced $B A X$ expression (Table 2). More specifically, knockdown of miR-15a expression resulted in enhanced PCNA expression, suggesting that this miR regulates cell proliferation, while knockdown of miR-105 and miR-182 reduces the expression of apoptotic markers, suggesting that these miRNAs stimulate apoptosis. Unfortunately, these studies neither explored the targets of these miRNAs, which may be regulated to modulate cell apoptosis/ proliferation, nor did they examine what factors may modulate the expression of these miRNAs.

Sirotkin et al. (2009) used an identical approach to identify miRNAs that regulate ovarian cell steroidogenesis. Thirty-six miRNAs that inhibited progesterone release and ten miRNAs that enhanced progesterone release were identified (Table 2). Transfection of granulosa cells with anti-miRs for miR-15a and miR-188 increased progesterone release, suggesting that these two miRNAs were capable of reducing progesterone release. Testosterone release was also affected by miRNAs with 57 miRNAs inhibiting testosterone release, while only one, miR-107, stimulating the release of this steroid (20\% above control values; Table 2). Lastly, 51 miRNAs inhibited estradiol $\left(E_{2}\right)$ release, while no miRNAs were identified that stimulated $E_{2}$ release (Table 2). Although these studies provide the initial identity of miRNAs, which may regulate ovarian granulosa cell steroid release, the mechanisms of action remain unknown.

More recently, two independent studies evaluated miRNA regulation and function using rodent granulosa cells. FSH regulation of miRNA expression on progesterone production using rat granulosa cells was evaluated in vitro. Granulosa cells were exposed to FSH and 17 miRNAs were identified as upregulated while 14 miRNAs were determined to be downregulated (Yao et al. 2010a). Of these, miR-23b increased 1.32 -fold, while miR-29a and miR-30d decreased (0.48- and 0.60-fold change respectively) at $12 \mathrm{~h}$ after $\mathrm{FSH}$ exposure. In contrast, both miR-23b and miR-30d expression increased at $48 \mathrm{~h}$ post-FSH administration. Bioinformatic analysis was used to predict putative targets of $m i R-29 a$ and miR-30d. COL4A1 and BMF (miR-29a targets) as well as RNF2 and EED (targets of miR-30d) expression decreased in response to FSH administration, suggesting that the expression of these FSH targets may be modulated by miRNAs. However, the role of these factors in granulosa cells was not examined in this study.

Yao et al. (2010b) also used mouse pre-antral granulosa cells to identify TGF $\beta-1$-regulated miRNAs. miR-125b-5p was one of the most significantly downregulated miRNAs while miR-224 was one of the most significantly upregulated. $m i R-224$ was identified as a potential mediator of TGF $\beta-1$ granulosa cell proliferation as forced expression of $m i R-224$ increased proliferation by targeting SMAD4. miR-224 was also shown to promote $\mathrm{E}_{2}$ release from granulosa cells and this may involve CYP19A1. Of the studies to date, this appears to be the most informative, providing not only information on the regulation of an ovarian miRNA but also its 


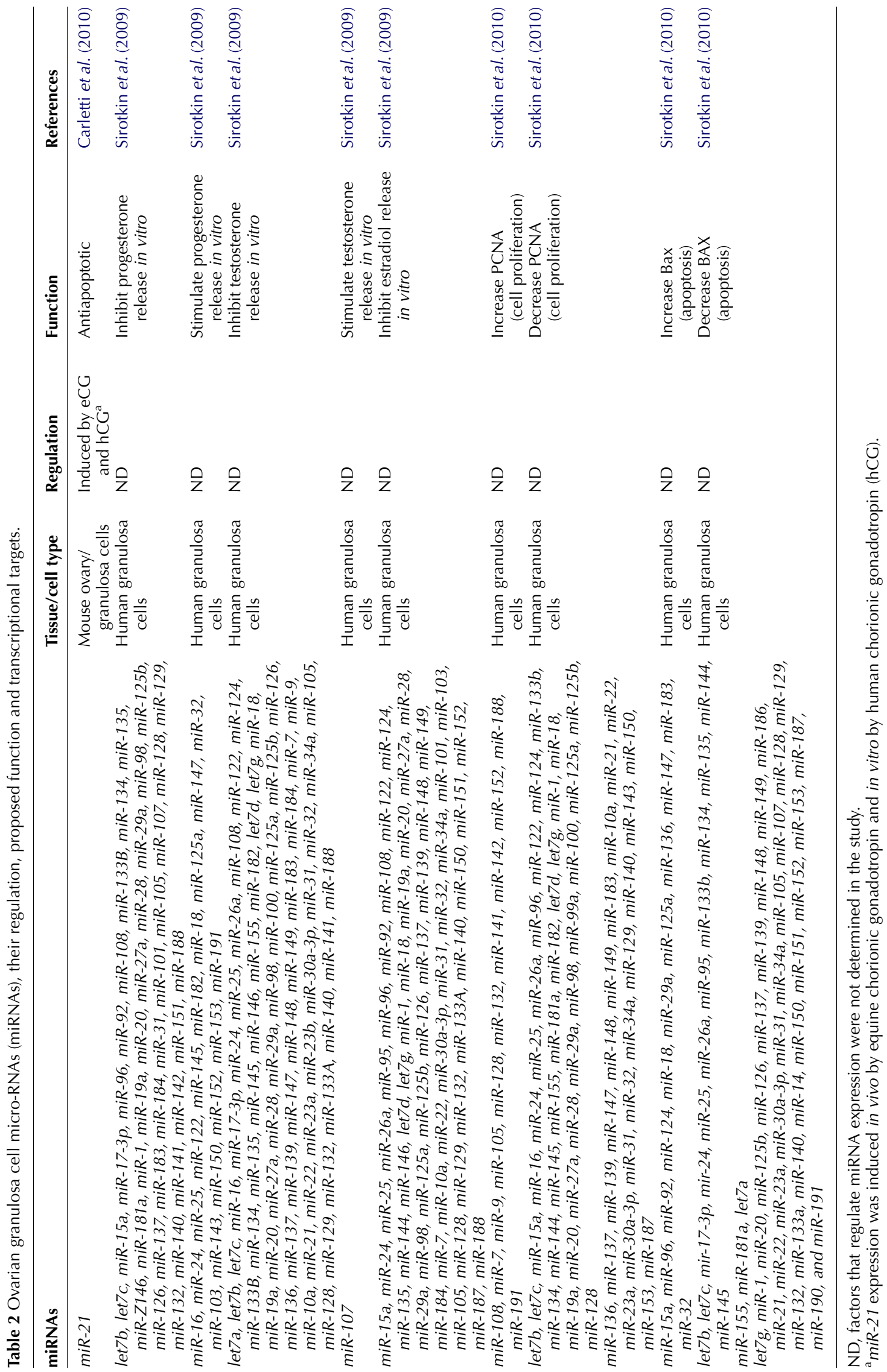


potential function and the targets through which it mediates these affects.

In addition to granulosa/follicular cells, substantial information exists on miRNA expression and potential function in ovarian surface epithelial (OSE) cells. The majority of these data are obtained from the comparisons between normal ovarian surface epithelium (NOSE) and cancerous OSE cells. Within the context of normal ovarian physiology, NOSE cells play a pivotal role in repair of the ovarian surface as a result of the ovulatory process. Early interest in the physiology and function of NOSE arose as it became apparent that these cells participate in ovulation and the tissue remodeling that occurs from this. However, with the discovery that the majority of ovarian cancers arise from the NOSE cells (Godwin et al. 1993) and subsequent miRNA profiling in ovarian cancer (lorio et al. 2007), these cells became the topic of much more thorough investigations for assessing miRNA function. Table 3 summarizes miRNA expression in ovarian NOSE compared with ovarian cancer tumor tissue and or cells, their validated targets, and proposed functional pathway, which they regulate.

Based upon the fact that ovarian cancer is a disease characterized by cell invasion, migration, and proliferation, it is not surprising that the bulk of studies assessing miRNA function have focused on miRNAs, which may regulate these pathways (Table 3). Some of the first studies demonstrated that the expression of the miR-200 family was correlated with the epithelial/mesenchymal phenotype of ovarian cancer cell lines (Park et al. 2008). This study as well as other studies (Bendoraite et al. 2010) demonstrated that $m i R-200 \mathrm{a} / \mathrm{b} / \mathrm{c}, \mathrm{miR}-141$, and miR-429 determines the epithelial phenotype of cancer cells by targeting the E-cadherin repressor proteins ZEB1 and ZEB2 as well as regulating oxidative stress via p38 $\alpha$ (Mateescu et al. 2011).

Over-expression of miRNAs in ovarian cancer tissue/ cells has also been associated with an inflammatory phenotype (Chen et al. 2008) and increased cell proliferation, invasion, and migration (Lou et al. 2010, Zhang et al. 2012a, 2012b). Over-expression

Table 3 Ovarian surface epithelial micro-RNAs (miRNAs), their expression level, proposed function, and transcriptional targets.

\begin{tabular}{|c|c|c|c|c|c|c|}
\hline miRNAs & Cell/tissue type & $\uparrow / \downarrow$ & Function & $\begin{array}{l}\text { Proposed } \\
\text { target }\end{array}$ & Validation $^{\mathrm{a}}$ & References \\
\hline \multirow[t]{3}{*}{$\operatorname{miR}-200 \mathrm{a} / \mathrm{b} / \mathrm{c}, \mathrm{miR}-141$} & NCl60 cell lines ${ }^{b}$ & & & & & \\
\hline & 'Epithelial phenotype' & $\uparrow$ & MET & ZEB1, ZEB2 & Yes & Park et al. (2008) \\
\hline & 'Mesenchymal phenotype' & $\downarrow$ & EMT & & & \\
\hline $\operatorname{miR}-200 \mathrm{a} / \mathrm{b} / \mathrm{c}$ & $\begin{array}{l}\text { HOSE cells, tumor tissue and } \\
\text { EOC cell lines }\end{array}$ & $\uparrow$ & MET & ZEB1, ZEB2 & Yes & $\begin{array}{l}\text { Bendoraite et al. } \\
\quad(2010)\end{array}$ \\
\hline \multicolumn{7}{|l|}{$\operatorname{miR}-141, \operatorname{miR}-429$} \\
\hline $\mathrm{miR}-200 \mathrm{a} / \mathrm{b} / \mathrm{c}$ & $\begin{array}{l}\text { Ovarian tumor tissue EOC } \\
\text { cell lines } \\
\text { d }\end{array}$ & $\uparrow$ & Oxidative stress & p38 $\alpha$ & Yes & $\begin{array}{l}\text { Mateescu et al. } \\
\quad(2011)\end{array}$ \\
\hline \multicolumn{7}{|l|}{$\operatorname{miR}-141, \operatorname{miR}-429$} \\
\hline miR-199a & $\begin{array}{l}\text { Primary EOC cells, EOC } \\
\text { cell lines }\end{array}$ & $\uparrow$ & Inflammation & $\mathrm{IKK} \beta$ & Yes & Chen et al. (2008) \\
\hline $\operatorname{miR}-9$ & Ovarian cancer cell line ES-2 & $\downarrow$ & Cell proliferation & $N F-\kappa B 1$ & Yes & Guo et al. (2009) \\
\hline $\operatorname{miR}-15 a$ & $\begin{array}{l}\text { Ovarian cancer tissue and } \\
\text { ovarian cancer cell lines }\end{array}$ & $\downarrow$ & $\begin{array}{l}\text { Cell proliferation, } \\
\text { clonal growth }\end{array}$ & Bmi1 & Yes & $\begin{array}{l}\text { Bhattacharya et al. } \\
\text { (2009) }\end{array}$ \\
\hline $\operatorname{miR}-16$ & & $\downarrow$ & & & & \\
\hline $\operatorname{miR}-34 a / b * / c$ & $\begin{array}{l}\text { Ovarian cancer tissue } \\
\text { OSE cells }\end{array}$ & $\downarrow$ & $\begin{array}{l}\text { Cell proliferation, } \\
\text { invasion, motility }\end{array}$ & MET & No & $\begin{array}{l}\text { Corney et al. } \\
\quad(2010)\end{array}$ \\
\hline $\operatorname{miR}-22$ & EOC cell lines $^{\mathrm{h}}$ & $\downarrow$ & $\begin{array}{l}\text { Cell migration, } \\
\text { invasion }\end{array}$ & $E S R 1^{i}$ & No & $\begin{array}{l}\text { Li et al. }(2010 a, \\
2010 b)\end{array}$ \\
\hline $\operatorname{miR}-21$ & $\begin{array}{l}\text { Ovarian cancer tissue EOC } \\
\text { cell lines }{ }^{j}\end{array}$ & $\uparrow$ & $\begin{array}{l}\text { Cell proliferation, } \\
\text { invasion, migration }\end{array}$ & PTEN & No & Lou et al. (2010) \\
\hline $\operatorname{miR}-25$ & EOC cell lines & $\uparrow$ & Cell proliferation & Bim & Yes & $\begin{array}{l}\text { Zhang et al. } \\
\qquad(2012 a, 2012 b)\end{array}$ \\
\hline $\operatorname{miR}-152$ & & $\downarrow$ & Cell proliferation & $\begin{array}{l}\text { Not } \\
\text { determined }\end{array}$ & No & Zhou et al. (2012) \\
\hline
\end{tabular}

MET, mesenchymal-to-epithelial transition/reduced aggressiveness; EMT, epithelial-to-mesenchymal transition/increased aggressiveness.

${ }^{a}$ Target validation was performed by 3'-UTR reporter construct assays and/or miR transfection and western analysis. ${ }^{\mathrm{b}} \mathrm{NCI} 60 \mathrm{cell}$ lines; see Liu. et al. mRNA and micro-RNA expression profiles of the NCl-60 integrated with drug activities. Molecular Cancer Therapeutics 9 1080-1091 (2010) for list of cell lines. 'Primary human ovarian surface epithelial (HOSE) cells, ovarian epithelial tumors, and ovarian cancer cell lines 2008, A1847, A2780, IGROV-1, OVCAR5, OVCAR10, PEO-1, A1847, CAOV3, ES-2, SKOV3, HEY, HAM, OVCAR3, OV90, TOV-21G, TOV-112D, and MCDB105 were studied. ${ }^{d}$ Cell lines studied were the EOC cell line SKOV3 as well as the mouse fibroblast cells, embryonic kidney cell line 293T, and human breast cancer cell line MDA-MD-468. ${ }^{e}$ Cell lines studied were cell lines SKOV3, A2780, and CP70. ${ }^{f}$ Cell lines studied were OVCAR-5, OV-167, CP70, A2780, and OV-202. ' ${ }^{\mathrm{m}} \mathrm{miRNA}$ expression was compared between EOC tumor tissue samples vs that in six normal ovarian surface epithelial primary cell samples. $\mathrm{h}$ High-metastatic human serous ovarian cancer cell SKOV-3ip and HO-8910PM were compared with respective relative lowmetastatic human serous ovarian cell lines SKOV-3 and HO-8910. 'ESR1 was a projected target whose expression was not assessed or validated. 'Epithelial ovarian cancer tissue, tissue from benign ovarian epithelial cysts, and normal ovarian tissue sections were used as well as OVCAR3 cells. 
of miR-199a was reported in ovarian cancer cell lines by Chen et al. (2008) who further demonstrated that IKK $\beta$ expression was reduced in these cells and correlated with pathways associated with inflammation. Over-expression of $m i R-21$ and miR-25 was independently reported by Lou et al. (2010) and Zhang et al. (2012a, 2012b), respectively, in ovarian cancer cell lines. Over-expression of miR-21 (Lou et al. 2010) was associated with reduced PTEN expression levels; however, it was not determined whether this was a direct or indirect effect of $m i R-21$ as functional validation was not performed. Over-expression of miR-25 (Zhang et al. 2012a, 2012b) was associated with increased cell proliferation, which was mediated via the miR-25 target Bim.

In addition to increased cell proliferation, migration, and invasion, which result from over-expression of specific miRNAs, there is also strong evidence that under-expression of specific miRNAs also leads to an increase in these cellular events. miR-9 regulates cell proliferation in ES-2 cancer cells by targeting NF-KB1 (Guo et al. 2009) while miR-15a and miR-16 were shown to regulate cell proliferation and clonal growth via Bmi1 (Bhattacharya et al. 2009). Functional validation studies confirmed that the impact of these miRNAs was directly on their respective targets. In addition to these miRNAs, miR-22 (Li et al. 2010a, $2010 b$ ) and $m i R-152$ (as well as $m i R-148$, but significantly; Zhou et al. 2012) have been shown to be suppressed in ovarian cancer cell lines, and this reduction was associated with cell migration and invasion $(m i R-22)$ as well as cell proliferation (miR-152). Li et al. speculated on the miR-22 targets that may be involved in the proliferative pathway but failed to validate ESR1 as a bonafide target. As such, although the data from these two studies clearly indicate that reduced expression of miR-22 and miR-152 is, respectively, associated with enhanced cell migration and invasion as well as proliferation, their targets and whether this is a direct or indirect effect remain to be determined.

In summary, within the contact of ovarian granulosa cells, miRNAs have been identified within the ovary, which are under regulation of $\mathrm{FSH} / \mathrm{LH}$ and appear to contribute to cell proliferation and/or apoptosis as well as steroid production/release. miRNA expression in ovarian surface epithelium has been primarily derived from studies using cancer specimens/cell lines. As such, our current knowledge on these miRNAs primarily focuses on those events conducive to cancer progression including cellular proliferation, invasion, and migration. The reader is encouraged to keep in mind that much of the data with regard to expression and function of miRNAs in OSE cells is compounded by the fact that there is a great deal of variability in the experimental designs. Some studies compare whole tissues (disease vs control) while some studies compare whole tissue vs isolated cells or cell lines. When assessing the data, one must carefully take into account the models used in these studies. Ideally, consistency should be maintained throughout for more accurate comparison among the study findings. Future research efforts should focus on deciphering the precise mechanisms by which miRNAs regulate these cellular processes within the ovary and whether alterations in the expression of these miRNAs and/or the pathways, which they regulate, are associated with ovarian insufficiencies with respect to ovulation, steroid production, cell differentiation, and infertility.

\section{Oviduct}

Despite the marked alteration in oviduct anatomy and function, which results from loss of Dicer function/ miRNA expression (Hong et al. 2008, Nagaraja et al. 2008, Gonzalez \& Behringer 2009), very little is known with respect to miRNA expression, regulation, and function within the oviduct. Nagaraja et al. (2008) performed deep sequencing of small RNAs in oviductal tissue from wild-type and Dicer1 conditional knockout mice and found that 28 miRNAs that were downregulated in knockout oviducts compared with wild type. mRNA targets of these miRNAs were predicted using TargetScan, PicTar, and miRanda algorithms. The majority of these miRNAs (23/28) were predicted to target genes that were upregulated and included Wnt5a, Cald1, Hoxa9, Hoxa10, Des, Apc (Min), and Tagln, factors involved in mesenchyme-derived structures and Müllerian duct differentiation. Based upon the inverse pattern of expression between these genes and their putative miRNA, it may be suggested that a Dicer1miRNA network may play a role in normal oviduct development and function.

In addition to this study, there is also limited information on miRNA expression, regulation, and function in human oviduct tissue/fallopian tube. Lee et al. (2009) used normal fallopian tube samples as control tissues for assessing miRNA expression in $B R C A 1 / 2$ mutation-carrying and nonmutation-carrying high-grade serous ovarian carcinomas. Compared with fallopian tube tissue, 19 miRNAs were significantly upregulated while nine miRNAs were significantly downregulated. Of these, five were further confirmed by qRT-PCR and verified that, compared with fallopian tubes, miR-34a, miR-143, and miR-145 were significantly lower in the ovarian cancer specimens, while miR-29a and $m i R-29 b$ were significantly higher. While none of these miRNAs were considered among the most abundantly expressed miRNAs in fallopian tube/oviduct tissue (Liang et al. 2007), all these miRNAs were detected in the study by Liang et al. (2007; $m i R-29 a>m i R-145>m i R-143>m i R-29 b>m i R-34 a)$.

While the study by Lee et al. (2009) did not address the potential functional significance of these miRNAs, 
one may speculate that based upon low expression in carcinoma tissue and the proposed targets (as determined by TargetScan, PicTar, and miRanda algorithms), that miR-34a, miR-143, and/or miR-145 may regulate pathways associated with cellular proliferation (Akao et al. 2010). Similarly, miR-29a and miR-29b, which were elevated in ovarian carcinomas, may regulate collagen-dependent extracellular matrix homeostasis. Li et al. (2009) have demonstrated that miR-29 suppresses the expression of several collagens. These observations, coupled with the fact that miR-29 increases MMP2/MMP9 expression via decreased DNA methylation (Chen et al. 2011), point toward a potential role of miR-29 in enhanced cell migration.

In summary, aside from these few studies, there is currently a paucity of information with respect to miRNA expression and, more so, function within the fallopian tube. Information gathered from animal models in which Dicer expression is deleted (Hong et al. 2008, Nagaraja et al. 2008, Gonzalez \& Behringer 2009) and miRNA expression is reduced (Nagaraja et al. 2008) strongly demonstrates a significant impact on oviductal phenotype and infertility. If we extrapolate data from other systems and take into account these potential functions, one may infer that miR-29a, miR-29b, miR-143, and miR-145 may regulate key pathways for the normal development and function of the oviducts. However, to be able to make such conclusions will require examination of these posttranscriptional regulators in this organ in more detail.

\section{Uterus: endometrium}

The majority of our information on uterine miRNAs has primarily been derived from studies that have compared miRNA expression between women without endometriosis ('normal' controls) to that of women with endometriosis. The intent of the discussion on uterine miRNAs is to outline miRNAs that have been identified in 'normal' uterine tissue. For those readers interested in miRNA expression between eutopic and ectopic/ endometriotic tissue and the potential function of these miRNAs in the pathogenesis of endometriosis, there are several recent publications and reviews (Ohlsson Teague et al. 2009, Teague et al. 2010, Ramón et al. 2011) on this topic.

The first assessment of endometrial miRNA expression was by Pan et al. (2007) in which they examined endometrial tissue from 'normal' women and compared that with endometrium from women with endometriosis to establish human endometrial miRNA profiles. Sixtyfive miRNAs were detected above a pre-determined threshold level. In endometrium from 'normal' women (women without endometriosis in this study), miR-125b, miR-21, miR-145, miR-26a, miR-23b, miR-29a, and miR-99a were among the most abundant. In endometrium from women with endometriosis as well as endometriotic tissue, there was a significant reduction in the expression of all these miRNAs as well as several other miRNAs. miRNA expression in normal endometrium was further assessed based upon cell type, focusing on endometrial stromal cells and glandular epithelial cells. Thirty-two miRNAs were shown to be differentially expressed between cell types. Of these, the investigators focused on examining the steroidal regulation of miR-20a, miR-21, and miR-26a. $\mathrm{E}_{2}$ decreased stromal cell expression of miR-20a and $m i R-21$ but increased expression of $m i R-26 a$, while medroxyprogesterone acetate significantly decreased expression of all the three miRNAs (Table 4). In glandular epithelial cells, $\mathrm{E}_{2}$ decreased expression of miR-20a and $m i R-21$ but increased expression of $m i R-26 a$, while

Table 4 Uterine cell micro-RNAs (miRNAs), their regulation, proposed function, and transcriptional targets.

\begin{tabular}{|c|c|c|c|}
\hline miRNAs & Cell/tissue type & Regulation & References \\
\hline $\operatorname{miR}-20 \mathrm{a}$ & \multirow[t]{3}{*}{ Human stromal cells (in vitro) } & $\mathrm{E}_{2}$ decreased/MPA decreased & \multirow[t]{3}{*}{ Pan et al. (2007) } \\
\hline $\operatorname{miR}-21$ & & $\mathrm{E}_{2}$ decreased/MPA decreased & \\
\hline $\operatorname{miR}-26 a$ & & $\mathrm{E}_{2}$ increased/MPA decreased & \\
\hline miR-20a & \multirow[t]{3}{*}{ Human glandular epithelial cells (in vitro) } & $\mathrm{E}_{2}$ decreased/MPA increased & \multirow[t]{3}{*}{ Pan et al. (2007) } \\
\hline $\operatorname{miR}-21$ & & $\mathrm{E}_{2}$ decreased/MPA decreased & \\
\hline $\operatorname{miR}-26 a$ & & $\mathrm{E}_{2}$ increased/MPA increased & \\
\hline $\operatorname{miR}-17-5 p$ & \multirow[t]{4}{*}{ Human stromal cells (in vitro) } & $\mathrm{E}_{2}$ increased/MPA increased & \multirow[t]{4}{*}{ Toloubeydokhti et al. (2008) } \\
\hline $\operatorname{miR}-542-3 p$ & & $\mathrm{E}_{2}$ increased/MPA increased & \\
\hline$m i R-23 a$ & & $\mathrm{E}_{2}$ decreased/MPA decreased & \\
\hline $\operatorname{miR}-23 b$ & & $\mathrm{E}_{2}$ decreased/MPA no affect & \\
\hline$m i R-17-5 p$ & \multirow[t]{4}{*}{ Human glandular epithelial cells (in vitro) } & $\mathrm{E}_{2}$ increased/MPA increased & \multirow[t]{4}{*}{ Toloubeydokhti et al. (2008) } \\
\hline$m i R-542-3 p$ & & $\mathrm{E}_{2}$ decreased/MPA decreased & \\
\hline $\operatorname{miR}-23 a$ & & $E_{2}$ decreased/MPA increased & \\
\hline$m i R-23 b$ & & $\mathrm{E}_{2}$ increased/MPA increased & \\
\hline $\operatorname{miR}-155$ & \multirow[t]{3}{*}{ Mouse uterus (in vivo) } & \multirow[t]{3}{*}{$\mathrm{E}_{2}$ increased } & \multirow[t]{3}{*}{ Nothnick and Healy (2010) } \\
\hline $\operatorname{miR}-429$ & & & \\
\hline $\operatorname{miR}-451$ & & & \\
\hline $\begin{array}{l}\operatorname{miR}-181 b \\
\operatorname{miR}-204\end{array}$ & Mouse uterus (in vivo) & $E_{2}$ decreased & Nothnick \& Healy (2010) \\
\hline
\end{tabular}

$\mathrm{E}_{2}, 17 \beta$ estradiol; MPA, medroxyprogesterone acetate. 
medroxyprogesterone acetate increased $m i R$-20a and $m i R-26 a$ but decreased miR-21 expression (Table 4).

In a subsequent study by this same group (Toloubeydokhti et al. 2008), miR-17-5p, miR-23a, miR-23b, and $m i R-542-3 p$ expression was assessed, and it was demonstrated that miR-23b and miR-542-3p were expressed in lower levels and that miR-17-5p was expressed at higher levels in paired eutopic and ectopic endometrial tissue compared with 'normal' eutopic endometrium. In isolated stromal cells, $E_{2}$ increased the expression of $m i R-17-5 p$ and $m i R$ $542-3 p$ but decreased the expression of miR-23a and $m i R-23 b$ (Table 4). MPA increased expression of $m i R-17-5 p$ and $m i R-542-3 p$, decreased the expression of $m i R-23 a$, and had no affect on miR-23b expression (Table 4). In isolated glandular epithelial cells, $E_{2}$ decreased the expression of $m i R-542-3 p$ and $m i R-23 a$ but increased the expression of $m i R-17-5 p$ and $m i R-23 b$ (Table 4). MPA increased the expression of all miRNAs but miR-542-3p, which was significantly decreased (Table 4). In this and the previously cited study (Pan et al. 2007), steroidal regulation could be blocked for some of the miRNAs with ICl-182780 and RU-486 co-treatment (respectively), suggesting a complex mechanism for steroidal regulation of miRNAs in endometrial stromal and glandular epithelial cells.

Burney et al. (2009) utilized a similar study design in comparing miRNA expression in early secretory endometrium from women with and without endometriosis. Early secretory endometrium from women with endometriosis expressed significantly lower levels of expression for $m i R-34 c-3 p, m i R-34 c-5 p, m i R-9, m i R-9 *$, $m i R-34 b^{*}$, and the unannotated miRPlus_42 780 . Although additional miRNA profile information was not provided in this report, one may conclude that these miRNAs are expressed in early secretory endometrium from women without endometriosis and may play a role within the endometrium during the menstrual cycle.

To date, only one study has examined miRNA expression in endometrial tissue/cells from women free of reproductive tract disorders such as endometriosis. Kuokkanen et al. (2010) assessed miRNA (and mRNA) expression between endometrial epithelial cells during the late proliferative and midsecretory menstrual phases in hopes of elucidating the action of progesterone in opposing the effects of estrogen on these parameters. Using bioinformatic analysis, the authors discovered that the differentially expressed mRNAs were associated with cell cycle regulation (enriched in late proliferative endometrial epithelium) and WNT signaling (enriched in proliferative phase endometrial epithelium). Twelve miRNAs were significantly upregulated in the midsecretory-phase specimens compared with those from the late proliferative phase and are proposed to target many cell cycle genes. In accordance with the function of miRNAs, miR-29b, miR-29c, miR-30b, miR-30d, miR31, miR-193a-3p, miR-203, miR-204, miR-200c, miR-
210, miR-582-5p, and miR-345 were upregulated while their target genes were decreased. These findings suggest that these miRNAs may regulate protein translation by reducing/inducing decay of cell cycle gene target transcripts and in turn suppress cell proliferation.

In addition to information gleaned from studies that incorporated human endometrial tissue, there is also limited information on miRNA profiles in mouse uterine tissue, with the bulk focusing on identifying miRNAs that are associated with and may play a role in embryo implantation. Initial characterization was performed by Chakrabarty et al. (2007) in which expression profiling was performed with oligonucleotide microarrays and compared the expression patterns of 380 miRNAs common to humans, mice, and rats, in day 1 (prereceptive; estrogen dominance) and day 4 (receptive; progesterone dominance) pregnant mouse uteri (where day 1 represents the presence of a vaginal plug). Thirtytwo miRNAs were upregulated during the receptive phase (progesterone dominance) and five were downregulated compared with the prereceptive (estrogen dominance) phase. Of those upregulated, miR-101a and miR-199a* were further examined and verified to regulate cyclo-oxygenase-2 (COX2) expression, an enzyme that is essential for embryo implantation. Additional studies have suggested that miR-21 (Hu et al. 2008), let7a (Xia et al. 2010a), and miR-320 (Xia et al. 2010b) may be important for embryo implantation in rodents.

A recent report from my laboratory (Nothnick \& Healy 2010) demonstrated by miRNA array and confirmed by qRT-PCR that miR-155, miR-429, and miR-451 are upregulated in the mouse uterus by estrogen while miR-181b and miR-204 are downregulated (Table 4). This regulation is mediated via the classical estrogen receptor pathway. Additional unpublished observations from our research group demonstrate that within the mouse uterus from ovariectomized mice, miR-709 is the most abundant miRNA followed by the let 7 family members and miR-26a.

Along the lines of estrogen regulation of uterine miRNAs, a recent study dissected the potential regulation of endometrial miRNAs and the mechanisms by which they regulate cellular proliferation. Zhang et al. (2012a, 2012b) demonstrated that estrogen increased estrogen receptor-positive endometrial adenocarcinoma cell proliferation and that this was associated with an upregulation of BCL2 and concurrent downregulation of BAX. As Bax repression was determined to occur posttranscriptionally, miRNA assessment revealed that members of the let7 family (let7a-g) and miR-27a targeted $B A X$ transcript. Surprisingly, as discussed above, none of these miRNAs were upregulated in human endometrial cells or mouse uterus in response to estrogen administration.

In addition to those studies that have addressed regulation of uterine miRNA expression, there is also 
emerging data on the function of miRNAs within endometrial cells with the bulk of this information derived from studies that have incorporated endometrial carcinoma cell lines. The first description and speculation on the function of miRNAs in endometrial/uterine tissue was presented by Pan et al. (2007). These authors proposed that many of the miRNAs expressed within the endometrium may regulate pathways that are essential to normal endometrial biology and, when dysregulated, lead to endometrial pathologies such as endometriosis and endometrial cancer. These pathways include inflammation, apoptosis, proliferation, angiogenesis, and differentiation. Our current understanding on the functional roles of specific miRNAs in endometrial cells is derived primarily from studies incorporating human endometrial adenocarcinoma cell lines as outlined below and summarized in Table 5 .

The majority of studies that have focused on determining the specific functional roles of miRNAs in endometrial cells primarily examined cell proliferation. Of the current data, the miR-200 family is the most well studied. Snowdon et al. (2011) reported that miR-200a/ $\mathrm{b} / \mathrm{c}, \mathrm{miR}-141$, and $\operatorname{miR}-429$ were upregulated in both endometrioid endometrial adenocarcinoma and complex atypical hyperplasia compared with normal control endometrium. Subsequent studies (Lee et al. 2011, Park et al. 2012) revealed similar studies in cancerous tissues as well as endometrial adenocarcinoma cell lines and further documented a functional role for these miRNAs. Use of anti-miRs for each of these miRNAs suppressed HEC-1A cell proliferation while only anti-miR-141,-200c, and -429 inhibitors reduced growth of Ishikawa cells (Lee et al. 2011). Park et al. (2012) further demonstrated that miR-200c could modulate cell proliferation, survival, and apoptosis in HEC-1A and Ishikawa cells. Further differential analysis of mRNA between cells transfected with control or premiR-200c revealed that miR-200c mediation of these cellular events was in part via downregulation of transcript for the tumor suppressor protein BRD7.

Three additional studies have evaluated the potential role of miRNAs in modulation of tumor suppressor genes in the context of endometrial adenocarcinomas. FOXO1 is also a tumor suppressor that is reduced in endometrial carcinoma (Goto et al. 2008, Myatt et al. 2010). Using miRNA target prediction programs, Myatt et al. (2010) identified a panel of highly conserved miRNAs that could potentially target the $3^{\prime}$-UTR of FOXO1 transcript. Of these, miR-9, miR-27, miR-96, miR-128, miR-153, $m i R-182$, miR-183, and miR-186 upregulation correlated with loss of FOXO1 expression in both endometrial carcinoma tissue and Ishikawa cells. Individual overexpression of all these miRNAs in HEC-1B cells except miR-128 reduced FOXO1 protein expression and when inhibitors of $m i R-9, \operatorname{miR}-27, \operatorname{miR}-96, \operatorname{miR}-153, \operatorname{miR}-183$, and $m i R-186$ were transfected as a pool into Ishikawa cells, cell cycle arrest and apoptosis were induced.

FOXC1 belongs to the same family of Forkhead box transcription factors as FOXO1 and its misexpression has also been associated with carcinogenesis (Myatt \& Lam 2007). Through analysis of differential expression, endometrial cancer expressed a set of dysregulated miRNAs that included miR-7, miR-149, miR-449b, and $m i R-204$. Of these, $m i R-204$ was shown to target FOXC1 and functionally regulate endometrial adenocarcinoma (HEC-1A) cell migration and invasion (Chung et al. 2012). Similarly, the tumor suppressor, TP53INP1, is also modulated by miRNAs and its miRNA-induced suppression is associated with enhanced cell proliferation (Jiang et al. 2011). More specifically, miR-125b was found to be upregulated in type II endometrial carcinoma cells. Over-expression and inhibition studies using adenocarcinoma cell lines revealed that miR-125b modulated in vitro and in vivo cell proliferation and invasion and that these events were mediated via TP53INP1.

In summary, miRNA profiles have been generated for human and rodent uterine tissues, and steroidal

Table 5 Uterine micro-RNAs (miRNAs), their expression level, proposed function, and transcriptional targets.

\begin{tabular}{|c|c|c|c|c|c|c|}
\hline miRNAs & Cell/tissue type & $\uparrow / \downarrow$ & Function & Proposed target & Validation $^{\mathrm{a}}$ & References \\
\hline $\mathrm{miR}-200 \mathrm{a} / \mathrm{b} / \mathrm{c}$ & $\begin{array}{l}\text { HEC-1A, Ishikawa cell } \\
\text { lines }\end{array}$ & $\uparrow$ & Proliferation & ND & Yes & Lee et al. (2011) \\
\hline \multicolumn{7}{|l|}{ miR-141, mir-429 } \\
\hline $\operatorname{miR}-200 \mathrm{C}$ & $\begin{array}{l}\text { HEC-1A, Ishikawa cell } \\
\text { lines }\end{array}$ & $\uparrow$ & Proliferation & BRD7 & Yes & Park et al. (2012) \\
\hline $\begin{array}{l}\text { miR-9, } \operatorname{miR}-27, \operatorname{miR}-96, \\
\text { miR-153, miR-182, } \\
\text { miR-183 }\end{array}$ & $\begin{array}{l}\text { Endometrial carcinoma } \\
\text { tissue, Ishikawa cells }\end{array}$ & $\uparrow$ & ND & $\begin{array}{l}\text { FOXO1 } \\
\quad \text { (decreased) }\end{array}$ & ND & Myatt et al. (2010) \\
\hline $\operatorname{miR}-186$ & HEC-1B cells & & Proliferation & FOXO1 & Yes & Myatt et al. (2010) \\
\hline $\begin{array}{l}\text { miR-7, miR-149, } \\
\quad \operatorname{miR}-449 b, \text { miR-204 }\end{array}$ & $\begin{array}{l}\text { Endometrial carcinoma } \\
\text { tissue }\end{array}$ & $\uparrow$ & ND & ND & ND & $\begin{array}{l}\text { Myatt \& Lam } \\
\quad(2007)\end{array}$ \\
\hline $\operatorname{miR}-204$ & HEC- 1 A cell line & & Migration, invasion & FOXC1 & Yes & $\begin{array}{l}\text { Myatt \& Lam } \\
\text { (2007) }\end{array}$ \\
\hline $\operatorname{miR}-125 b$ & $\begin{array}{l}\text { Type II endometrial } \\
\text { carcinoma cells }\end{array}$ & $\uparrow$ & $\begin{array}{l}\text { Proliferation invasion } \\
\quad \text { (in vitro and in vivo) }\end{array}$ & TP53INP1 & Yes & Jiang et al. (2011) \\
\hline
\end{tabular}

ND, function or proposed target was not determined in the study.

aTarget validation was performed by $3^{\prime}$-UTR reporter construct assays and/or miR transfection and western analysis. 
regulation of some of these miRNAs have been examined in isolated stromal and glandular epithelial systems. Emerging data from studies that have incorporated that human endometrial adenocarcinoma cell lines has shed some insight into the potential function of these miRNAs within the cells of the endometrium and the pathways by which they may do so. The majority of the current information suggests that uterine miRNAs appear to regulate cellular proliferation, migration, and/or invasion and that the members of the miR-200 family appear to be major players in these processes.

\section{Uterus: myometrium}

The myometrium is the muscular wall of the uterus and lies between the internal layer (endometrium) and the outer layer (the perimetrium). The chief function of the myometrium is during the birth process to provide the contractile forces necessary for expulsion of the fetus. During pregnancy, high progesterone levels keep the myometrium/uterus quiescent. Renthal et al. (2010) recently examined the potential role of miRNAs as mediators of hormonally modulated contractile targets in the pregnant uteri of both humans and mouse. Microarray analysis was performed on myometrial tissue from mice before (day 15.5 postcoital) and just before term pregnancy (day 18.5 post-coital with day 19 being term). The $m i R-200$ family $(m i R-200 \mathrm{a} / \mathrm{b} / \mathrm{c}$, $m i R-141$, and $m i R-429$ ) was upregulated in myometrium from the day 18.5 group compared with the day 15.5 group (Table 6). Associated with this upregulation was a decrease in the expression of proposed targets, ZEB1 and ZEB2. miR-200 family and ZEB1/ZEB2 expression was conserved between mouse and human as the miR-200 family was upregulated and ZEB1 and ZEB2 downregulated in laboring human myometrium compared with myometrium from term, nonlaboring women. Associated with the downregulation of ZEB1/ ZEB2 in both mouse and human myometrium was an increase in expression of CXN43 and OXTR. Additional mouse models of preterm labor were used and revealed that there was an upregulation of the miR-200 family and downregulation of ZEB1/ZEB2.
It was further revealed that ZEB1 is directly upregulated by progesterone and that ZEB1 and ZEB2 inhibit the expression of contractile proteins CXN43 and OXTR. Collectively, these findings suggest that progesterone regulates the expression of the miR-200 family and their targets ZEB1 and ZEB2 in modulating uterine contractility during pregnancy and labor.

Outside of this single report on miRNAs in myometrial tissue during pregnancy, the majority of our understanding on miRNA expression, function, and regulation in myometrial tissue and/or cells comes from studies focusing on the role of miRNAs in the pathogenesis of uterine fibroids. The first study to assess myometrial miRNA expression was conducted by Wang et al. (2007) where they generated a miRNA signature associated with race, tumor size, and target gene activity. Two hundred and six miRNAs were examined and 45 were found to be dysregulated in uterine leiomyomas. Of these, the five most significantly upregulated miRNAs in leiomyomas were let7 family, miR-21, miR-23b, $m i R-27 a$, and miR-30a. let7 expression was significantly higher in small $(<3 \mathrm{~cm})$ leiomyomas compared with large $(>10 \mathrm{~cm})$ leiomyomas, and there was an inverse correlation between let7 expression and its proposed target HMGA2 and validity of target was confirmed by transfection of leiomyoma cells with let7 (Table 6). In addition to the upregulated miRNAs, miR-29b, miR-32, miR-144, miR-197, and miR-212 were also shown to be significantly downregulated in leiomyomas. While the predicted targets for all of these miRNAs were reported by Wang et al. (2007), other than let7, none of them were validated in their study.

A subsequent study by Marsh et al. (2007) identified 46 miRNAs that were differentially expressed in leiomyomas of which 19 were upregulated and 27 were downregulated. Of these, miR-542-3p was the most significantly upregulated (11.8-fold) and miR-498 was the most significantly downregulated (2.4-fold). While the authors validated the expression of $m i R-21$, miR-34a, miR-125b, miR-139, and miR-323 by qRT-PCR, they did not examine regulation or function of these miRNAs in the pathogenesis of leiomyomas. As $m i R-542-3 p$ has been proposed and validated to target

Table 6 Myometrial micro-RNAs (miRNAs), their expression regulation, proposed function, and transcriptional targets.

\begin{tabular}{|c|c|c|c|c|c|c|}
\hline miRNAs & Cell/tissue type & $\uparrow / \downarrow$ & Function & Proposed target & Validation $^{\mathrm{a}}$ & References \\
\hline $\begin{array}{l}\mathrm{miR}-200 \mathrm{a} / \mathrm{b} / \mathrm{c} \\
\mathrm{miR}-141 \\
\operatorname{miR}-429\end{array}$ & $\begin{array}{l}\text { Myometrium (human) } \\
\text { Myometrium (mouse) }\end{array}$ & $\uparrow$ by $\mathrm{P}_{4}$ & Uterine quiescence & ZEB1/ZEB2 & No & Renthal et al. (2010) \\
\hline $\begin{array}{l}\mathrm{miR}-200 \mathrm{a} / \mathrm{b} / \mathrm{c} \\
\mathrm{miR}-141 \\
\mathrm{miR}-429\end{array}$ & UtLM leiomyoma cell line & $\downarrow$ & Cell growth & TUBB, CYP1B1, СТВP2 & Yes & Zavadil et al. (2010) \\
\hline let7 & Leiomyoma tissue and cells & ND & $\begin{array}{l}\text { Adipogenesis, } \\
\text { mesenchymal } \\
\text { differentiation }\end{array}$ & HMGA2 & Yes & Wang et al. (2007) \\
\hline
\end{tabular}

$\mathrm{P}_{4}$, progesterone; ND, not determined.

${ }^{\mathrm{a}}$ Target validation was performed by $3^{\prime}$-UTR reporter construct assays and/or, miR transfection, and western analysis. 
survivin and suppress cell growth (Yoon et al. 2010), the potential role of this miRNA in the pathogenesis of leiomyomas is unclear at this time. miR-498 has been proposed to target ZEB2 (based on upon TargetScan analysis). Thus, reduced levels of miR-498 in leiomyomas may be associated with increased levels of ZEB2. However, the potential role of ZEB2 in the pathogenesis of leiomyomas has yet to be examined.

Pan et al. (2008) evaluated miRNA expression profiles in paired myometrium and leiomyoma tissue, myometrial smooth muscle cells (MSMCs) and leiomyoma smooth muscle cells (LSMC) isolated from these tissues, as well as in the leiomyoma cell lines T-LSMC and SK-LMS-1. They identified 91 miRNAs that were expressed above myometrium thresholds. Of these, miR-20a, miR-21, miR-26a, mir-18a, miR-206, miR$181 a$, and miR-142-5p were confirmed by qRT-PCR and their steroidal regulation assessed in MSMC, LSMC, T-LSMC, and SK-LMS-1. Leiomyomas expressed higher levels of miR-20a, miR-21, miR-26a, and miR-206 compared with myometrium. miR-142-5p expression was lower in leiomyomas compared with myometrium from Caucasians but not in African Americans. African Americans also expressed lower levels of miR-181a in leiomyomas compared with matched myometrium while Caucasians expressed higher levels of $m i R-181 a$ in leiomyoma tissue vs myometrium.

When cells isolated from leiomyoma (LSMC) and myometrium tissue (MSMC) were compared with tLSMC and SKLM cell lines, it was revealed that both cell lines expressed significantly higher levels of expression of miR-20a and miR-26a compared with both MSMC and LSMC, but LSMC expression was lower than that in MSMC. In contrast, miR-21 expression was lower in LSMC, tLSMC, and SKLM compared with MSMC, but the cell lines exhibited significantly greater levels of $m i R-21$ expression compared with MSMC.

Examination of the steroidal regulation of these three miRNAs in MSMC and LSMC revealed that estrogen and progesterone modulated miRNA expression in a celltype and steroid-specific manner. Specifically, estrogen decreased miR-21 expression in MSMC but not in LSMC. The progesterone analog, MPA, increased miR-21 expression in LSMC but not in MSMC. Further, both estrogen and MPA increased miR-26a expression in MSMC but reduced expression of this miRNA in LSMC. Neither estrogen nor MPA affected miR-20a expression in either MSMC or LSMC.

More recently, Zavadil et al. (2010) profiled and analyzed the function of miRNAs and their target products in human leiomyoma tissue. Using uterine leiomyomas $(>10 \mathrm{~cm})$ from African American women, predicted gene targets of the five most highly upregulated (miR-21, miR-23b, miR-27a, miR-30a, and let $7 s)$ and downregulated (miR-29b, miR-32, miR-144, miR197 , and miR-212) miRNAs were determined by miRNA prediction methods (TargetScan and PicTar). There were
249 downregulated putative mRNA targets that corresponded with the five upregulated miRNAs and 97 upregulated putative mRNA targets that corresponded with the five downregulated miRNAs. Of the dysregulated mRNAs, protein localization was assessed for 16 of these (EGFR, ESR1 (ER $\alpha)$, GRIP1, Hamartin, HMGA1, HMGA2, IGF1, IGF2, Ki-67, TYMP (PD-ECGF), PIK3R1 (PI3K), PGR (PR-A), RARA (RAR $\alpha$ ), RXRA (RXR $\alpha)$, TGFA, and TSC2). There was an inverse correlation between $\mathrm{Ki}$ 67 expression and that of LET7. Moderate negative correlations were found between EGFR and miR-194-1 as well as between TGF $\alpha$ and $m i R-199 a-2$. Overall, most gene products and their corresponding miRNAs exhibited negative correlations.

One interesting aspect of the study by Zavadil et al. (2010) was the further functional validation of the $m i R-200$ family and its putative targets. Both miR-200a and miR-200b were downregulated in leiomyomas while many of their targets were upregulated. To demonstrate validity of a portion of these targets, UtLM cells, which stably over-express miR-200a, were evaluated for protein expression and cell growth. Overexpression of miR-200a was associated with reduced levels of TUBB, CYP1B1, and CTBP2 and this reduction in protein expression was correlated with growth inhibition (Table 6), suggesting that the reduced level of miR-200a may impact cell growth relevant to the pathophysiology of uterine leiomyomas.

In summary, myometrial miRNAs (miR-200 family) appear to be necessary for normal pregnancy and labor where they regulate uterine contractility. Outside of this report, most of our information on myometrial miRNAs is derived from studies, which have focused on differential profiles between myometrium and leiomyomas (fibroids). Along these lines, current information is primarily limited to assessment of cell growth and proliferation and steroidal regulation of myometrial/ leiomyoma miRNAs. As myometrial function is essential to parturition, additional studies are required to enhance our understanding on the regulation and function of miRNAs within this muscle layer. This analysis should also expand into myometrial dysfunction not only associated with the pathogenesis of uterine leimyomas but also abnormal myometrial function/contraction during abnormal labor/birth.

\section{Cervix}

Understanding the biology of the cervix is essential to the understanding of process of normal parturition as well as abnormalities in this process. In an attempt to determine whether cervical dilatation and remodeling after term parturition in the human were associated with changes in miRNA expression, Hassan et al. (2010) assessed cervical biopsy specimens from patients who had delivered spontaneously (term; labor) compared with patients who underwent elective cesarean section with 
an unripe cervix (term; not in labor). miRNA analysis revealed that 226 miRNAs were expressed in human term cervical tissue. Of these, $m i R-223, m i R-34 b$, and $m i R-34 c$ were upregulated in cervical tissue from women who underwent spontaneous labor compared with those who did not. miRBase algorithm was used to predict protein targets of these miRNAs. Using previously published microarray data, genes that may be targeted by these miRNAs whose expression was significantly upregulated were identified and included Claudin-8 (miR-223 target), arachidonate 12-lipoxygenase (miR-34b target), and calmodulinlike-3 (miR-34c target).

Most of our understanding on miRNA expression within the cervix has been derived from studies using human cervical cancer specimens and/or cervical cancer cell lines (Lui et al. 2007, Lee et al. 2008, Martinez et al. 2008, Wang et al. 2008, Li et al. 2010a, 2010b). Lui et al. (2007) used cervical carcinoma cell lines (SW756, C4I, C33A, CaSki, SiHa, and ME-180) and normal cervical specimens to generate cervical miRNA profiles. One hundred and sixty-six miRNAs were expressed in cervical cancer cell lines and normal cervical tissue; six miRNAs were differentially expressed between the two cell/tissue types. Two miRNAs in particular (miR-21 and miR-143) were further examined in matched pairs of human cervical cancer and normal cervical samples. Increased expression of $m i R-21$ and reduced expression of miR-143 were noted in the cervical cancer specimens, suggesting that these miRNAs may prove useful as tumor markers.

Subsequently, Lee et al. (2008) used qRT-PCR to assess miRNA expression in early stage invasive squamous cell carcinomas and normal cervical squamous epithelial specimens. Sixty-eight miRNAs were upregulated and two were downregulated in carcinoma specimens. Two of the most significantly upregulated miRNAs were $m i R-127$ and $m i R-199 a$. miR-127 expression was significantly associated with lymph node metastasis. Using SiHa and ME-180 cancer cell lines transfected with anti-miR-199a, the investigators demonstrated that $m i R-199 a$ expression was associated with cell growth and that incorporation of anti-miR-199a oligonucleotides with the anticancer agent cisplatin potentiated the suppression of cell growth by this agent.

CaSki-2 cervical cancer cells were used to clone 174 miRNAs of which miR-21, miR-24, miR-27a, and miR-205 were the most abundant with one novel miRNA (miR-193c) also being reported (Wang et al. 2008). Ten of the 174 miRNAs were further studied. $m i R-143$ and $m i R-145$ expression was undetectable in the cervical cancer cell lines as well as cervical cancer tissue and $m i R-126$ was also downregulated in the tissue specimens. In contrast, miR-15b, miR-16, miR-146a, and $\operatorname{miR}-155$ were upregulated in cervical cancer tissue specimens. To assess the potential role of some of these miRNAs in cervical carcinogenesis, functional studies were conducted. miR-143 and miR-145 were shown to suppress cell growth, suggesting that their downregulation/absence in cervical cancer cells/tissue may promote cell proliferation. In contrast, miR-146a promoted cell proliferation, suggesting that the detected upregulation of the miRNA in cervical cancer may be growth promoting.

Subsequent studies have assessed the potential impact of miRNA dysregulation in cervical cancer and cell proliferation (Table 7). $m i R-21$ is perhaps the most wellstudied miRNA among cancer biology (Fu et al. 2011) and is considered a major regulator of cell proliferation. Using HeLa cells, Yao et al. (2009) demonstrated that miR-21 knockdown suppresses cell proliferation, colony growth, and colony size. Associated with these decreases was an increase in the tumor suppressor PDCD4 protein levels. Luciferase reporter assays were used to validate PDCD4 as a direct target of miR-21. While $m i R-21$ appears to be upregulated in cervical cancers, miR-100 (Li et al. 2011a, 2011b) and miR-372 (Tian et al. 2011) expression is reduced. miR-100 expression was examined in normal cervical epithelium, cervical intraepithelial neoplasia, and cervical cancer in addition to five cervical cell lines (Li et al. 2011a, 2011b). qRT-PCR analysis revealed that miR-100 was highest in normal cervical epithelium and decrease with increasing stage of cancer. Functional significance of reduced miR-100 was confirmed by over-expression/ knockdown studies, and it was determined that $m i R-100$ regulated cell proliferation, cell cycle, and apoptosis. Further, these effects of miR-100 were mediated at least in part through regulation of the mitotic checkpoint protein, PLK1, whose expression is elevated in cervical cancer (Gao et al. 2006). In a similar manner, miR-372 was shown to regulate cell growth and that this involved targeting of CDK2 and cyclin A1. Collectively, these data imply that the upregulated expression of $m i R-21$ characteristic of cervical cancer most likely enhance cell proliferation via downregulation of PDCD4 while the suppressed levels of miR-100 and miR-372 may modulate cell proliferation via PLK1 and CDK2/cyclin A1 respectively.

In addition to alterations in cell proliferation pathways, two recent studies have focused on the pro-apoptotic pathways. P2RX7 (P2X7) is a membranebound, ligand-operated channel that mediates apoptosis, which is expressed in normal human ectocervical tissue and human ectocervical-vaginal epithelial cells (hEVECs) but is down regulated in ectocervical cancer and HeLa cells as well as endometrial cancer (Zhou et al. 2008). Associated with this reduction in $P 2 R X 7$ expression is an elevation of $m i R-186 a$ and $m i R-150$ in HeLa cells compared with hEVEC cells. To determine whether these miRNAs play a functional role in the regulation of $P 2 R X 7$, hEVEC, and HeLa cells were transfected with miR-186 and miR-150 inhibitors. Both 
Table 7 Cervical micro-RNAs (miRNAs), their expression level, proposed function, and transcriptional targets.

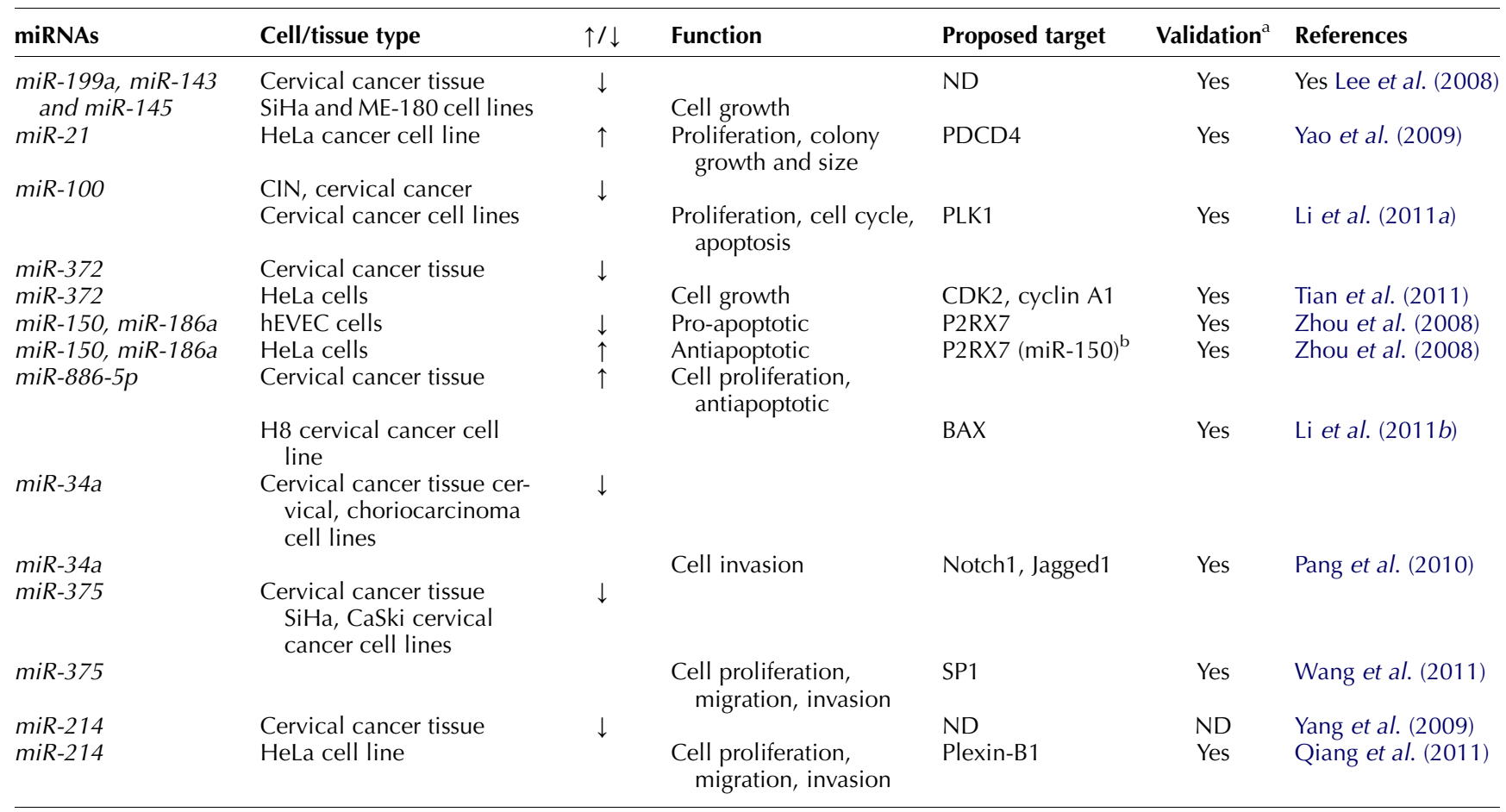

ND, not determined; CIN, cervical intraepithelial neoplasia; hEVEC, human ectocervical vaginal epithelial cells.

${ }^{a}$ Target validation was performed by $3^{\prime}$-UTR reporter construct assays and/or miR transfection and western analysis. ${ }^{\mathrm{b}} \mathrm{miR}-150$ but not $\mathrm{miR}-186 \mathrm{a}$ targeted P2RX7 in HeLa cells.

miR-186 and miR-150 inhibitors increased $P 2 R X 7$ mRNA levels in hEVEC cells, but only miR-150 inhibitor increased $P 2 R X 7$ expression in HeLa cells. Collectively, these data suggest that the elevated levels of miR-186 and $m i R-150$ in ectocervical cancerous tissue and cell lines may induce a downregulation of $P 2 R X 7$ and thereby an inhibition of apoptosis. Along these lines, miR-886-5p was also demonstrated to inhibit apoptosis and be over-expressed in cervical cancer tissue ( $\mathrm{Li}$ et al. $2011 a, 2011 b$ ). Forced expression of $m i R-886-5 p$ in the cervical cancer cell line $\mathrm{H} 8$ was associated with reduced apoptosis and increased cell proliferation. This effect of miR-886-5p was demonstrated to be mediated via a direct effect on the pro-apoptotic protein, BAX. Collectively, these data demonstrate that over-expression of miR-186, miR-150, and miR-886-5p characteristic of cervical cancer functionally contributes to the pathogenesis by modulating the expression of antiapoptotic proteins.

In addition to cell proliferation, miRNAs have also been associated with cell invasion. Using an array of cervical and choriocarcinoma cell lines, Pang et al. (2010) demonstrated that miR-34a reduces cell invasion by targeting NOTCH1 and JAGGED1. Similarly, expression of miR-375 was reported to be reduced in cervical cancer tissue (Wang et al. 2011). Forced expression of miR-375 in both SiHa and CaSki cells was associated with reduced cell proliferation (significant G1 arrest) and reduced migration and invasion. Associated with this miR-375-induced suppression of cell proliferation, migration, and invasion was a reduction in the expression of the transcription factor, SP1. Lastly, miR-214 expression has also been reported to be reduced in cervical cancer and associated with enhanced cell growth (Yang et al. 2009). In a follow-up study by this group, Qiang et al. (2011) reported that $m i R-214$ expression was inversely correlated with that of plexin-B1 and a direct repressor of this target mRNA. Forced expression of miR-214 in HeLa cells was also associated with reduced cell proliferation, migration, and invasion. Taken together, recent studies demonstrate that miR-34a, miR-375, and miR-214 modulate cell invasion and their reduced expression in cervical cancer leads to enhanced cell migration, invasion, and proliferation.

In summary, the majority of our information on miRNA expression in the cervix is derived from studies using cancer specimens/cell lines. Of these, miR-21 and miR-143 appear to be the most well studied and both modulate cell proliferation. In cancer cells, $m i R-21$ is over-expressed while miR-143 is underexpressed and their patterns of expression are reversed in normal cervical tissue/cells. In addition to our information on miRNAs gleaned from cancer studies, parturition studies have identified a subset of miRNAs $(m i R-223, m i R-34 b$, and $m i R-34 c)$, which are 
associated with cervical ripening/parturition as well as cell proliferation and apoptosis. While the presented studies provide the initial miRNA expression profiles in this organ, future studies will need to emphasize dissecting the function of the miRNAs, their transcriptional targets, and the mechanisms by which these miRNAs regulate the cellular events within the cervix both from the normal function of this organ and from dysregulation of miRNAs and the development of cervical cancer.

\section{Conclusions}

Conditional deletion of the miRNA-processing enzyme DICER1 has revealed that miRNAs are essential for normal development and function of the mouse female reproductive tract. Additional studies have examined the expression, regulation, and function of miRNAs in the female reproductive tract of not only mice but also more of humans. miRNA expression profiles have been generated for ovary, oviduct, endometrium, myometrium, and cervix in both normal and diseased tissue as well as various cell lines. These studies not only provide a profile of miRNA expression but also to help understand what miRNAs may be misexpressed in diseases of the female reproductive tract and how dysregulation of these miRNAs contribute to the pathogenesis of the disease.

Overall, our understanding on the regulation of miRNA expression in the female reproductive tract is superficial. Studies are warranted to further define the roles of miRNAs in organ development, organ dysfunction, disease, and neoplasia. Additional emphasis should focus on identifying the precise mechanisms of miRNA expression in these processes. While we must appreciate the information obtained to date, we must also keep in mind that the majority of putative targets for those misexpressed miRNAs have yet to be validated. We must also exercise caution when extrapolating data from cancer cell lines to that of normal reproductive organ cells and tissues. To deepen our understanding, future approaches should focus on miRNA target identification, validation, and function of these miRNA transcript target pathways within each component of the female reproductive tract. This should start with localization of miRNAs of interest and concurrent assessment of those putative targets of relevancy in the same cells within each tissue. Patterns of expression for miRNA and protein should be inverse if in fact the specific miRNA is posttranscriptionally regulating the putative target. Next, it is essential to validate these mRNA targets, and this can be done through a combination of miRNA restoration/knockdown, western blot analysis, and 3'-UTR reporter constructs. As technology advances so will our ability to further dissect the mechanisms of miRNA regulation as well as the pathways that these miRNAs regulate within the organs of the female reproductive tract.

\section{Declaration of interest}

The authors declare that there is no conflict of interest that could be perceived as prejudicing the impartiality of the review reported.

\section{Funding}

This review did not receive any specific grant from any funding agency in the public, commercial or not-for-profit sector.

\section{Acknowledgements}

The author thanks Ms Arlene Colvin for her critical review of the draft version of this manuscript.

\section{References}

Ahn HW, Morin RD, Zhao H, Harris RA, Coarfa C, Chen Z-J, Milosavljevic A, Marra MA \& Rajkovic A 2010 MicroRNA transcriptome in the newborn mouse ovaries determined by massive parallel sequencing. Molecular Human Reproduction 16 463-471. (doi:10.1093/molehr/gaq017)

Akao Y, Nakagawa Y, Hirata I, lio A, Itoh T, Kojima K, Nakashima R, Kitade Y \& Naoe T 2010 Role of anti-oncomers miR-143 and -145 in human colorectal tumors. Cancer Genetics and Cytogenetics 17 398-408. (doi:10.1038/cgt.2009.88)

Bartel DP 2004 MicroRNAs: genomics, biogenesis, mechanism, and function. Cell 116 281-297. (doi:10.1016/S0092-8674(04)00045-5)

Bendoraite A, Knouf EC, Garg KS, Parkin RK, Kroh EM, O'Briant KC, Ventura AP, Godwin AK, Karlan BY, Drescher CW et al. 2010 Regulation of miR-200 family microRNAs and ZEB transcription factors in ovarian cancer: evidence supporting a mesothelial-to-epithelial translation. Gynecologic Oncology 116 117-125. (doi:10.1016/j.ygyno.2009. 08.009)

Berezikov E, Chung WJ, Willis J, Cuppen E \& Lai EC 2007 Mammalian mitron genes. Molecular Cell 28 328-336. (doi:10.1016/j.molcel.2007. 09.028)

Bhattacharya R, Nicoloso M, Arvizo R, Wang E, Cortez A, Rossi S, Calin GA \& Mukherjee P 2009 MiR-15a and MiR-16 control Bmi-1 expression in ovarian cancer. Cancer Research 69 9090-9095. (doi:10.1158/00085472.CAN-09-2552)

Burney RO, Hamilton AE, Aghajanova L, Vo KC, Nezhat CN, Lessey BA \& Giudice LC 2009 MicroRNA expression profiling of eutopic secretory endometrium in women with versus without endometriosis. Molecular Human Reproduction 15 625-631. (doi:10.1093/molehr/gap068)

Cai X, Hagedorn CH \& Cullen BR 2004 Human microRNAs are processed from capped, polyadenylated transcripts that can also function as mRNAs. RNA 10 1957-1966. (doi:10.1261/rna.7135204)

Calabrese JM, Seila AC, Yeo GW \& Sharp PA 2007 RNA sequence analysis defines Dicer's role in mouse embryonic stem cells. PNAS 104 18097-18102. (doi:10.1073/pnas.0709193104)

Carletti MZ, Fiedler SD \& Christenson LK 2010 MicroRNA 21 blocks apoptosis in muse periovulatory granulosa cells. Biology of Reproduction 83 286-295. (doi:10.1095/biolreprod.109.081448)

Chakrabarty A, Tranguch S, Daikoku T, Jensen K, Furneaux H \& Dey SK 2007 MicroRNA regulation of cyclooxygenase-2 during embryo implantation. PNAS 104 15144-15149. (doi:10.1073/pnas. 0705917104)

Chen R, Alvero AB, Silasi DA, Kelly MG, Fest S, Visintin I, Leiser A, Schwartz PE, Rutherford T \& Mor G 2008 Regulation of IKKbeta by miR-199a affects NF-kappaB activity in ovarian cancer cells. Oncogene 27 4712-4723. (doi:10.1038/onc.2008.112) 
Chen KC, Wang YS, Hu CY, Chang WC, Liao YC, Dai CY \& Hank Juo SH 2011 OxLDL up-regulates microRNA-29b, leading to epigenetic modifications of MMP-2/MMP-9 genes: a novel mechanism for cardiovascular diseases. FASEB Journal 25 1718-1728. (doi:10.1096/fj. 10-174904)

Chendrimada TP, Finn KJ, Ji X, Baillat D, Gregory RI, Liebhaber SA, Pasquinelli AE \& Shiekhattar R 2007 MicroRNA silencing through RISC recruitment of elF6. Nature 447 823-828. (doi:10.1038/nature 05841)

Childs A, Kinnell HL, He J \& Anderson RA 2012 LIN28 is selectively expressed in primordial and pre-meiotic germ cells in the human fetal ovary. Stem Cells and Development . (doi:10.1089/scd.2011.0730)

Choi Y, Qin Y, Berger MF, Ballow DJ, Bulyk ML \& Rajkovic A 2007 Microarray analysis of newborn mouse ovaries lacking Nobox. Biology of Reproduction 77 312-319. (doi:10.1095/biolreprod.107.060459)

Chung TK, Lau TS, Cheung TH, Yim SF, Lo KW, Siu NS, Chan LK, Yu MY, Kwong J, Doran G et al. 2012 Dysregulation of microRNAs-204 mediates migration and invasion of endometrial cancer by regulating FOXC1. International Journal of Cancer 130 1036-1045. (doi:10.1002/ ijc.26060)

Corney DC, Hwang CI, Matoso A, Vogt M, Flesken-Nikitin A, Godwin AK, Kamat AA, Sood AK, Ellenson LH, Hermeking $\mathbf{H}$ et al. 2010 Frequent downregulation of miR-34 family in human ovarian cancers. Clinical Cancer Research 16 1119-1128. (doi:10.1158/1078-0432.CCR-092642)

Coutinho LL, Matukumali LK, Sonstegard TS, Van Tassell CP, Gasbarre LC, Capuco AV \& Smith TP 2007 Discovery and profiling of bovine microRNAs from immune-related and embryonic tissue. Physiological Genomics 29 35-43.

Fiedler SD, Carletti MZ, Hong X \& Christenson LK 2008 Hormonal regulation of microRNA expression in periovulatory mouse mural granulosa cells. Biology of Reproduction 79 1030-1037. (doi:10.1095/ biolreprod.108.069690)

Fu X, Han Y, Wu Y, Zhu X, Lu X, Mao F, Wang X, He X, Zhao Y \& Zhao Y 2011 Prognostic role of microRNA-21 in various carcinomas: a systematic review and meta-analysis. European Journal of Clinical Investigation 41 1245-1253.

Gao Q, Huang X, Tang D, Cao Y, Chen G, Lu Y, Zhuang L, Wang S, Xu G, Zhou J et al. 2006 Influence of chk1 and plk1 silencing on radiation- or cisplatin-induced cytotoxicity in human malignant cells. Apoptosis $\mathbf{1 1}$ 1789-1800. (doi:10.1007/s10495-006-9421-4)

Godwin AK, Testa JR \& Hamilton TC 1993 The biology of the ovarian cancer development. Cancer 71 530-536. (doi:10.1002/cncr. 2820710207)

Gonzalez G \& Behringer RR 2009 Dicer is required for female reproductive tract development and fertility in the mouse. Molecular Reproduction and Development 76 678-688. (doi:10.1002/mrd.21010)

Goto T, Takano M, Albergaria A, Briese J, Pomeranz KM, Cloke B, Fusi L, Feroze-Zaidi F, Maywald N, Sajin M et al. 2008 Mechanism and functional consequences of loss of FOXO1 expression in endometrioid endometrial cancer cells. Oncogene 27 9-19.

Guo LM, Pu Y, Han Z, Liu T, Li YX, Liu M, Li X \& Tang H 2009 MicroRNA-9 inhibits ovarian cancer cell growth through regulation of NF-kappaB1. FEBS Journal 276 5537-5546. (doi:10.1111/j.1742-4658. 2009.07237.x)

Harfe BD, McManus MT, Mansfield JH, Hornstein E \& Tabin CJ 2005 The RNaselll enzyme Dicer is required for morphogenesis but not patterning of the vertebrate limb. PNAS 102 10898-10903. (doi:10.1073/pnas. 0504834102)

Harris KS, Zhang Z, McManus MT, Harfe BD \& Sun X 2006 Dicer function is essential for lung epithelium morphogenesis. PNAS 103 2208-2213. (doi:10.1073/pnas.0510839103)

Hassan SS, Romero R, Pineles B, Tarca AL, Montenegro D, Erez O, Mittal P, Kusanovic JP, Mazaki-Tovi S, Espinoza J et al. 2010 MicroRNA expression profiling of the human uterine cervix after term labor and delivery. American Journal of Obstetrics and Gynecology 202 80e1-80e8. (doi:10.1016/j.ajog.2009.08.016)

Hayashi K, Chuva de Sousa Lopes SM, Kaneda M, Tang F, Hajkova P, Lao K, O'Carroll D, Das PP, Tarakhovsky A, Miska EA et al. 2008 MicroRNA biogenesis is required for mouse primordial germ cell development and spermatogenesis. PLOS ONE 3 e1738. (doi:10.1371/journal.pone. 0001738)
Hong X, Luense LJ, McGinnis LK, Nothnick WB \& Christenson LK 2008 Dicer1 is essential for female fertility and normal development of the female reproductive system. Endocrinology 149 6207-6212. (doi:10.1210/en.2008-0294)

Hu SJ, Ren G, Liu JL, Zhao ZA, Yu YS, Su RW, Ma XH, Ni H, Lei W \& Yang ZM 2008 MicroRNA expression and regulation in mouse uterus during embryo implantation. Journal of Biological Chemistry 283 23473-23484. (doi:10.1074/jbc.M800406200)

Huse JT, Brennan C, Hambardzumyan D, Wee B, Pena J, Rouhanifard SH, Sohn-Lee C, le Sage C, Agami R, Tuschl T et al. 2009 The PTENregulating microRNA miR-26a is amplified in high-grade glioma and facilitates gliomagenesis in vivo. Genes and Development 23 1327-1337.

Hutvagner G \& Simard MJ 2008 Argonaute proteins: key players in RNA silencing. Nature Reviews. Molecular Cell Biology 9 22-32. (doi:10.1038/nrm2321)

Iorio MV, Visone R, Di Leva G, Donati V, Petrocca F, Casalini P, Taccioli C, Volinia S, Liu CG, Alder H et al. 2007 MicroRNA signatures in human ovarian cancer. Cancer Research 67 8699-8707. (doi:10.1158/00085472.CAN-07-1936)

Jackson RJ \& Standart N 2007 How do microRNAs regulate gene expression? Science's STKE 367 re1. (doi:10.1126/stke.3672007re1)

Jiang F, Liu T, He Y, Yan Q, Chen X, Wang H \& Wan X 2011 MiR-125b promotes proliferation and migration of type II endometrial carcinoma cells through targeting TP53INP1 tumor suppressor in vitro and in vivo. BMC Cancer 11 425. (doi:10.1186/1471-2407-11-425)

Kuokkanen S, Chen B, Ojalvo L, Benard L, Santoro N \& Pollard JW 2010 Genomic profiling of microRNAs and messenger RNAs reveals hormonal regulation in microRNA expression in human endometrium. Biology of Reproduction 82 791-801. (doi:10.1095/biolreprod.109.081059)

Lee JW, Choi CH, Choi JJ, Park YA, Kim SJ, Hwang SY, Kim WY, Kim TJ, Lee JH, Kim BG et al. 2008 Altered microRNAs expression in cervical carcinoma. Clinical Cancer Research 14 2535-2542. (doi:10.1158/ 1078-0432.CCR-07-1231)

Lee CH, Subramanian S, Beck AH, Espinosa I, Senz J, Zhu SX, Huntsman D, van de Rijn M \& Gilks CB 2009 MicroRNA profiling of BRCA1/2 mutation-carrying and non-mutation-carrying high-grade serous carcinomas of ovary. PLOS ONE 4 e7314. (doi:10.1371/journal.pone. 0007314)

Lee JW, Park YA, Choi JJ, Lee YY, Kim CJ, Choi C, Kim TJ, Lee NW, Kim BG \& Bae DS 2011 The expression of the miRNA-200 family in endometrial endometrioid carcinoma. Gynecologic Oncology 120 56-62. (doi:10.1016/j.ygyno.2010.09.022)

Lei L, Jin S, Gonzalez G, Behringer RR \& Woodruff TK 2010 The regulatory role of Dicer in folliculogenesis in mice. Molecular and Cellular Endocrinology 315 63-73. (doi:10.1016/j.mce.2009.09.021)

Li B, Hy Y, Ye F, Li Y, Lv W \& Xie X 2010a Reduced miR-34a expression in normal cervical tissues and cervical lesions with high-risk human papillomavirus infection. International Journal of Gynecological Cancer 20 597-604. (doi:10.1111/IGC.0b013e3181d63170)

Li J, Liang S, Yu H, Zhang J, Ma D \& Lu X 2010b An inhibitory effect of miR-22 on cell migration and invasion in ovarian cancer. Gynecologic Oncology 119 543-548. (doi:10.1016/j.ygyno.2010.08.034)

Li BH, Zhou JS, Ye F, Cheng XD, Zhou CY, Lu WG \& Xie X 2011 a Reduced miR-100 expression in cervical cancer and precursors and its carcinogenic effect through targeting PLK1 protein. European Journal of Cancer 47 2166-2174. (doi:10.1016/j.ejca.2011.04.037)

Li Z, Hassan MQ, Jafferji M, Ageilan RI, Garzon R, Croce $C M$, van Wijnen AJ, Stein JL, Stein GS \& Lian JB 2009 Biological functions of miR$29 \mathrm{~b}$ contribute to positive regulation of osteoblast differentiation. Journal of Biological Chemistry 284 15676-15684.

Li JH, Xiao X, Zhang YN, Wang YM, Feng LM, Wu YM \& Zhang XY 2011 b MicroRNA-886-5p inhibits apoptosis by down-regulating Bax expression in human cervical carcinoma cells. Gynecologic Oncology $\mathbf{1 2 0}$ 145-151. (doi:10.1016/j.ygyno.2010.09.009)

Liang Y, Ridzon D, Wong L \& Chen C 2007 Characterization of microRNAs expression profiles in normal human tissue. BMC Genomics 8166. (doi:10.1186/1471-2164-8-166)

Liu XX, Li XJ, Zhang B, Liang YJ, Zhou CX, Cao DX, He M, Chen GQ, He JR \& Zhao Q 2011 MicroRNA-26b is underexpressed in human breast cancer and induces cell apoptosis by targeting SLC7A11. FEBS Letters 585 1363-1367. (doi:10.1016/j.febslet.2011.04.018) 
Lou Y, Yang X, Wang F, Cui Z \& Huang Y 2010 MicroRNA-21 promotes the cell proliferation, invasion and migration abilities in ovarian epithelial carcinomas through inhibiting the expression of PTEN protein. International Journal of Molecular Medicine 26 819-827. (doi:10.3892/ ijmm_00000530)

Lu J, He ML, Wang L, Chen Y, Liu X, Dong Q, Chen YC, Peng Y, Yao KT, Kung HF et al. 2011 MiR-26a inhibits cell growth and tumorigenesis of nasopharyngeal carcinoma through repression of $\mathrm{EZH} 2$. Cancer Research 71 225-233. (doi:10.1158/0008-5472.CAN-10-1850)

Lui W-O, Pourmand N, Patterson BK \& Fire A 2007 Patterns of known and novel small RNAs in human cervical cancer. Cancer Research $\mathbf{6 7}$ 6031-6043. (doi:10.1158/0008-5472.CAN-06-0561)

Marsh EE, Lin Z, Yin P, Milad M, Chakravanti D \& Bulun SE 2007 Differential expression of microRNAs species in human uterine leiomyoma versus normal myometrium. Fertility and Sterility 89 1771-1776. (doi:10.1016/j.fertnstert.2007.05.074)

Martinez I, Gardiner AS, Board KF, Monzon FA, Edwards RP \& Khan SA 2008 Human papillomavirus type 16 reduces the expression of microRNA-218 in cervical carcinoma cells. Oncogene 27 2575-2582. (doi:10.1038/sj.onc.1210919)

Mateescu B, Batista L, Cardon M, Gruosso T, de Feraudy Y, Mariani O, Nicolas A, Meyniel JP, Cottu P, Sastre-Garau X et al. 2011 miR-141 and miR-200a act on ovarian tumorigenesis by controlling oxidative stress response. Nature Medicine 17 1627-1635. (doi:10.1038/nm.2512)

Medeiros LE, Dennis LM, Gill ME, Houbaviy H, Markoulaki S, Fu D, White AC, Kirak O, Sharp PA, Page DC et al. 2011 mir-290-295 deficiency in mice results in partially penetrant embryonic lethality and germ cell defects. PNAS 108 14163-14168. (doi:10.1073/pnas. 1111241108)

Mishima T, Takizawa T, Luo SS, Ishibashi O, Kawahigashi Y, Mizuguchi Y, Ishikawa T, Mori M, Kanda T, Goto T et al. 2008 MicroRNA (miRNA) cloning analysis reveals sex differences in miRNA expression profiles between adult mouse testis and ovary. Reproduction 136 811-822. (doi:10.1530/REP-08-0349)

Myatt SS \& Lam EW 2007 The emerging roles of forkhead box (Fox) proteins in cancer. Nature Reviews. Cancer 7 847-859. (doi:10.1038/nrc2223)

Myatt SS, Wang J, Monteiro LJ, Chrisitan M, Ho KK, Fusi L, Dinea RE, Brosens JJ, Ghaem-Maghami S \& Lam EW 2010 Definition of microRNAs that repress expression of the tumor suppressor gene FOXO1 in endometrial cancer. Cancer Research 70 367-377. (doi:10.1158/00085472.CAN-09-1891)

Nagaraja AK, Andreu-Vieyra C, Franco HL, Ma L, Chen RH, Han DY, Zhu HF, Agno JE, Gunaratne PH, DeMayo FJ et al. 2008 Deletion of Dicer in somatic cells of the female reproductive tract causes sterility. Molecular Endocrinology 22 2336-2352. (doi:10.1210/me.2008-0142)

Nothnick WB \& Healy C 2010 Estrogen induces distinct patterns of microRNA expression within the mouse uterus. Reproductive Sciences 17 987-994. (doi:10.1177/1933719110377472)

Ohlsson Teague EM, Van der Hoek KH, Van der Hoek MB, Perry N, Wagaarachchi P, Robertson SA, Print CG \& Hull LM 2009 MicroRNAregulated pathways associated with endometriosis. Molecular Endocrinology 23 265-275. (doi:10.1210/me.2008-0387)

O'Rourke JR, Georges SA, Seay HR, Tapscott SJ, McManus MT, Goldhamer DJ, Swanson MS \& Harfe BD 2007 Essential role for Dicer during skeletal muscle development. Developmental Biology 311 359-368. (doi:10.1016/j.ydbio.2007.08.032)

Otsuka M, Zheng M, Hayashi M, Lee JD, Yoshino O, Lin S \& Han J 2008 Impaired microRNAs processing causes corpus luteum insufficiency and infertility in mice. Journal of Clinical Investigation 118 1944-1954. (doi:10.1172/JCl33680)

Pan Q, Luo X, Toloubeydokhti T \& Chegini N 2007 The expression profile of micro-RNA in endometrium and endometriosis and the influence of ovarian steroids on their expression. Molecular Human Reproduction 13 797-806. (doi:10.1093/molehr/gam063)

Pan Q, Luo X \& Chegini N 2008 Differential expression of microRNAs in myometrium and leiomyomas and regulation by ovarian steroids. Journal of Cellular and Molecular Medicine 12 227-240.

Pang RT, Leung CO, Ye TM, Liu W, Chiu PC, Lam KK, Lee KF \& Yeung WS 2010 MicroRNA-34a suppresses invasion through downregulation of Notch1 and Jagged1 in cervical carcinoma and choriocarcinoma cells. Carcinogenesis 31 1037-1044. (doi:10.1093/carcin/bgq066)
Park SM, Caur AB, Lengyel E \& Peter ME 2008 The miR-200 family determine the epithelial phenotype of cancer cells by targeting the E-cadherin repressors ZEB1 and ZEB2. Genes and Development 22 894-907. (doi:10.1101/gad.1640608)

Park YA, Lee JW, Choi JJ, Jeon HK, Cho Y, Choi C, Kim TJ, Lee NW, Kim BG \& Bae DS 2012 The interactions between microRNA-200c and BRD7 in endometrial carcinoma. Gynecologic Oncology 124 125-133. (doi:10.1016/j.ygyno.2011.09.026)

Qiang R, Wang F, Shi LY, Liu M, Chen S, Wan HY, Li YX, Li X, Gao SY, Sun BC et al. 2011 Plexin-B1 is a target of miR-214 in cervical cancer and promotes the growth and invasion of HeLa cells. International Journal of Biochemistry \& Cell Biology 43 632-641. (doi:10.1016/j. biocel.2011.01.002)

Ramón LA, Braza-Boïls A, Gilabert-Estellés J, Gilabert J, España F, Chirivella M \& Estellés A 2011 microRNA expression in endometriosis and their relationship to angiogenic factors. Human Reproduction $\mathbf{2 6}$ 1082-1090. (doi:10.1093/humrep/der025)

Renthal NE, Chen CC, Williams KC, Gerard RD, Prange-Kiel J \& Mendelson CR 2010 miR-200 family and targets ZEB1 and ZEB2, modulate uterine quiescence and contractility during pregnancy and labor. PNAS 107 20828-20833. (doi:10.1073/pnas.1008301107)

Ro S, Song R, Park C, Zheng H, Sandeers KM \& Yan W 2007 Cloning and expression profiling of small RNAs expressed in mouse ovary. RNA 13 2366-2388. (doi:10.1261/rna.754207)

Saini HK, Griffiths-Jones S \& Enright AJ 2007 Genomic analysis of human microRNA transcripts. PNAS 104 17719-17724. (doi:10.1073/pnas. 0703890104)

Sander S, Bullinger L, Klapproth K, Fiedler K, Kestler HA, Barth TF, Moller P, Stilgenbauer S, Pollack JR \& Wirth T 2008 MYC stimulates $\mathrm{EZH} 2$ expression by repression of its negative regulator miR-26a. Blood 112 4202-4212.

Sirotkin AV, Ovcharenko D, Grossmann R, Lauková M \& Mlynčk M 2009 Identification of microRNAs controlling human ovarian cell steroidogenesis via a genome-scale screen. Journal of Cellular Physiology 219 415-420. (doi:10.1002/jcp.21689)

Sirotkin AV, Lauková M, Ovcharenko D, Brenaut P \& Mlynčk M 2010 Identification of microRNAs controlling human ovarian cell proliferation and apoptosis. Journal of Cellular Physiology 223 49-56. (doi:10.1002/ jcp.21999)

Snowdon J, Zhang X, Childs T, Tron VA \& Feilotter H 2011 The microRNAs200 family is upregulated in endometrial carcinoma. PLOS ONE 6 e22828. (doi:10.1371/journal.pone.0022828)

Takada S, Berezikov E, Choi YL, Yamashita Y \& Mano H 2009 Potential role of $m i R-29 b$ in modulation of Dnmt3a and Dnmt3b expression in mouse primordial germ cells of the female mouse embryos. RNA $\mathbf{1 5}$ 1507-1514. (doi:10.1261/rna.1418309)

Tang X, Gal J, Zhuang X, Wang W, Zhu H \& Tang G 2007 A simple array platform for microRNA analysis and its application in mouse tissues. RNA 13 1803-1822. (doi:10.1261/rna.498607)

Teague EM, Print CG \& Hull ML 2010 The role of microRNAs in endometriosis and associated reproductive conditions. Human Reproduction Update 16 142-165. (doi:10.1093/humupd/dmp034)

Tian RQ, Wang XH, Hou LJ, Jia WH, Yang Q, Li YX, Liu M, Li X \& Tang H 2011 MicroRNA-372 is down-regulated and targets cyclin-dependent kinase 2 (CDK2) and Cyclin A1 in human cervical cancer, which may contribute to tumorigenesis. Journal of Biological Chemistry $\mathbf{2 8 6}$ 25556-25563. (doi:10.1074/jbc.M111.221564)

Toloubeydokhti T, Pan Q, Luo X, Bukulmez O \& Chegini N 2008 The expression and ovarian steroid regulation of endometrial microRNAs. Reproductive Sciences 15 993-1001. (doi:10.1177/1933719108 324132)

Vasudevan S, Tong Y \& Steitz JA 2007 Switching from repression to activation: microRNAs can up-regulate translation. Science $\mathbf{3 1 8}$ 1931-1934. (doi:10.1126/science.1149460)

Wang T, Zhang X, Obijuru L, Laser J, Aris V, Lee P, Mittal K, Soteropoulos P \& Wei J-J 2007 A micro-RNA signature associated with race, tumor size and target gene activity in human uterine leiomyomas. Genes, Chromosomes \& Cancer 46 336-347. (doi:10.1002/gcc.20415)

Wang X, Tang S, Le SY, Lu R, Rader JS, Meyers C \& Zheng ZM 2008 Aberrant expression of oncogenic and tumor-suppressive microRNAs in cervical cancer is required for cancer cell growth. PLOS ONE 3 e2557. (doi:10.1371/journal.pone.0002557) 
Wang F, Li Y, Zhou J, Xu J, Peng C, Ye F, Shen Y, Lu W, Wan X \& Xie X 2011 miR375 is down-regulated in squamous cervical cancer and inhibits cell migration and invasion via targeting transcription factor SP1. American Journal of Pathology 179 2580-2588. (doi:10.1016/j.ajpath.2011.07.037)

West JA, Viswanathan SR, Yabuuchi A, Cunniff K, Takeuchi A, Park IH, Sero JE, Zhu H, Perez-Atayde A, Frazier AL et al. 2009 A role for Lin28 in primordial germ-cell development and germ-cell malignancy. Nature 460 909-913.

Wong CF \& Tellam RL 2008 MicroRNA-26a targets the histone methyltransferase enhancer of Zeste homolog 2 during myogenesis. Journal of Biological Chemistry 283 9836-9843.

Xia HF, Jin XH, Song PP, Cui Y, Liu CM \& Ma X 2010a Temporal and spatial regulation of let-7a in the uterus during embryo implantation in the rat. Journal of Reproduction and Development 56 73-78. (doi:10.1262/jrd. 09-088K)

Xia HF, Jin XH, Song PP, Cui Y, Liu CM \& Ma X $2010 b$ Temporal and spatial regulation of miR-320 in the uterus during embryo implantation in the rat. International Journal of Molecular Sciences 11 719-730. (doi:10.3390/ijms11020719)

Yang Z, Chen S, Luan X, Li Y, Liu M, Li X, Liu T \& Tang H 2009 MicroRNA214 is aberrantly expressed in cervical cancers and inhibits the growth of HeLa cells. IUBMB Life 61 1075-1082. (doi:10.1002/iub.252)

Yao Q, Xu H, Zhang QQ, Zhou H \& Qu LH 2009 MicroRNA-21 promotes cell proliferation and down-regulates the expression of programmed cell death 4 (PDCD4) in HeLa cervical carcinoma cells. Biochemical and Biophysical Research Communications 388 539-542. (doi:10.1016/j. bbrc.2009.08.044)

Yao N, Yang B-Q, Liu Y, Tan X-Y, Lu C-L, Yuan X-H \& Ma X 2010a Folliclestimulating hormone regulation of microRNAs expression on progesterone production in cultured rat granulosa cells. Endocrine $\mathbf{3 8}$ 158-166. (doi:10.1007/s12020-010-9345-1)

Yao G, Yin M, Lian J, Tian H, Liu L, Li X \& Sun F $2010 b$ MicroRNA-224 is involved in transforming growth factor-beta-mediated mouse granulosa cell proliferation and granulosa cell function by targeting Smad4. Molecular Endocrinology 24 540-551. (doi:10.1210/me.2009-0432)
Yoon S, Choi YC, Lee S, Jeong Y, Yoon J \& Baek K 2010 Induction of growth arrest by miR-542-3p that targets survivin. FEBS Letters $\mathbf{5 8 4}$ 4048-4052. (doi:10.1016/j.febslet.2010.08.025)

Zavadil J, Ye H, Liu Z, Wu J, Lee P, Hernando E, Soteropoulos P, Toruner GA \& Wei JJ 2010 Profiling and functional analyses of microRNAs and their target gene products in human uterine leiomyomas. PLOS ONE 5 e12362. (doi:10.1371/journal.pone.0012362)

Zhang B, Liu XX, He JR, Zhou CX, Guo M, He M, Li MF, Chen GQ \& Zhao Q 2011 Pathologically decreased miR-26a antagonizes apoptosis and facilitates carcinogenesis by targeting MTDH and EZH2 in breast cancer. Carcinogenesis 32 2-9.

Zhang H, Zuo Z, Lu X, Wang L, Wang H \& Zhu Z 2012a MiR-25 regulates apoptosis by targeting Bim in human ovarian cancer. Oncology Reports 27 594-598.

Zhang R, He Y, Zhang X, Xing B, Sheng Y, Lu H \& Wei Z $2012 b$ Estrogen receptor-regulated microRNAs contribute to the BCL2/BAX imbalance in endometrial adenocarcinoma and precancerous lesions. Cancer Letters 314 155-165. (doi:10.1016/j.canlet.2011.09.027)

Zhou L, Qi X, Potashkin JA, Abdul-Karim FW \& Gorodeski GI 2008 MicroRNAs miR-186 and miR-150 down-regulate expression of the pro-apoptotic purinergic $\mathrm{P} 2 \mathrm{X} 7$ receptor by activation of instability sites at the $3^{\prime}$-untranslated region of the gene that decreases steady-state levels of the transcript. Journal of Biological Chemistry 283 28274-28286. (doi:10.1074/jbc.M802663200)

Zhou X, Zhao F, Wang ZN, Song YX, Chang H, Chiang Y \& Xu HM 2012 Altered expression of miR-152 and miR-148 in ovarian cancer is related to cell proliferation. Oncology Reports 27 447-454.

Received 30 June 2011

First decision 17 August 2011

Revised manuscript received 19 March 2012

Accepted 21 March 2012 